\title{
THE PRESENCE OF AN ORBITOANTORBITAL FENESTRA: FURTHER EVIDENCE OF THE ANUROGNATHID PECULIARITY WITHIN THE PTEROSAURIA
}

\author{
FABIO MARCO DALLA VECCHIA
}

Institut Català de Paleontologia (ICP), Edifici ICP, Campus de la Universitat Autònoma de Barcelona, E-08193 Cerdanyola del Vallès, Spain. E-mail: fabio.dallavecchia@icp.cat

Associate Editor: Silvio Renesto.

To cite this article: Dalla Vecchia F.M. (2022) - The presence of an orbitoantorbital fenestra: further evidence of the anurognathid peculiarity within the Pterosauria. Riv. It. Paleontol. Strat., 128(1): 23-42.

Keywords: Reptilia; Flying reptiles; Anurognathidae; Batrachognathus volans; Skull; Anatomy.

Abstract - The anurognathids are peculiar pterosaurs characterized by broad skulls with very short rostra and broadly arched jaws. The presence of distinct or confluent external naris and antorbital fenestra in these pterosaurs has been debated in the last years. The relatively well-preserved specimens of Batrachognathus volans show that the antorbital fenestra was confluent with the orbit forming an enormous orbitoantorbital fenestra. This feature is evident also in Jeholopterus ningchengensis. The consequent modification of the matrices of two recently published phylogenetic analyses about the in-group pterosaur relationships shows that the Anurognathidae are a derived clade of non-monofenestratan pterosaurs. Anurognathidae (including also 'Dimorphodon' weintraubi according to the definition by Hone 2020) are still a scarcely known clade because only a few specimens have been adequately described in the literature.

\section{INTRODUCTION}

Pterosaurs are extinct archosaur reptiles that lived during the Mesozoic Era and were the first vertebrates to evolve the powered flight. The oldest pterosaurs found to date are Late Triassic (Norian, ca. 220 million years ago) in age, while the last are latest Maastrichtian (ca. 66 million years ago) in age (Dalla Vecchia 2013; Dalla Vecchia et al. 2013). The non-monofenestratan pterosaurs had a moderately elongated skull with five fenestrae (openings) in laterodorsal view: narial, antorbital, orbital, lower temporal and upper temporal fenestrae. In monofenestratan pterosaurs (Darwinoptera +

Received: June 22, 2021; accepted: September 27, 2021
Pterodactyliformes according to Andres et al. 2014), the narial and antorbital fenestrae are confluent forming a nasoantorbital fenestra.

Anurognathidae is a peculiar pterosaur clade that has been recently reviewed by Hone (2020) and Wei et al. (2021). According to the definition of Anurognathidae by Hone (2020) (see below) and the phylogenetic hypothesis by Wei et al. (2021), the clade includes eight monospecific named genera and no more than 15 reported specimens (Wei et al. 2021). Until 2002, only three anurognathid species, each represented by a single and incomplete described specimen were known: Anurognathus ammoni Döderlein, 1923, Batrachognathus volans Ryabinin, 1948 and Dendrorbynchoides curvidentatus (Ji \& Ji, 1998). Later, Jeholopterus ningchengensis Wang, Zhou, Zhang \& Xu, 2002; Luopterus mutoudengensis (Lü \& Hone, 2012); Vesperopterylus lamadongensis Lü, Meng, 
Wang, Liu, Shen \& Zhang, 2018; and Sinomacrops bondei Wei, Pêgas, Shen, Guo, Ma, Sun \& Zhou, 2021 were added to the list.

Unnamed and only preliminarily described anurognathids are reported from the Sinuiju Beds (Lower Cretaceous) of North Korea (Gao et al. 2009) and the Middle Jurassic of China (Jiang et al. 2015). Also a partial specimen from the Middle Jurassic of Mongolia (Unwin \& Bakhurina 2000) and Mesadactylus ornithosphyos Jensen \& Padian, 1989 from the Upper Jurassic of USA (Bennett 2007) have been reported as potential anurognathids. However, Hone (2020) considers Mesadactylus ornithosphyos to be a pterodactyloid.

The phylogenetic analyses by Britt et al. (2018), Dalla Vecchia (2019) and Wei et al. (2021) have recovered Dimorphodon weintraubi Clark, Hopson, Hernández, Fastovsky \& Montellano 1998 as the sister taxon of all (Wei et al. 2021) or some (Britt et al. 2018; Dalla Vecchia 2019) of the anurognathid taxa listed above. This supports the view by Britt et al. (2018) that Dimorphodon weintraubi does not belong to Dimorphodon and should be referred to a distinct genus. According to the definition of Anurognathidae by Hone (2020), 'Dimorphodon' weintraubi is an anurognathid in these phylogenetic hypotheses.

All the anurognathid specimens are smallsized (maximum $900 \mathrm{~mm}$ in wingspan; excluding the only specimen of 'Dimorphodon' weintraubi, which is larger), preserved crushed on slabs, incomplete and/or partly disarticulated. For these reasons, their delicate skeletal elements are difficult to identify and subject to subjective interpretations. These specimens span the Middle Jurassic (Callovian or possibly Aalenian) to the Early Cretaceous (Aptian) and come from central-eastern Asia and Germany; the basal 'Dimorphodon' weintraubi is slightly older (Toarcian) and comes from Mexico. All the specimens but the two from Germany are preserved into rocks of continental origin; all the continental anurognathids come from lacustrine facies, excluding ' $D i$ morphodon' weintraubi.

The position of the anurognathids (sensu Hone 2020) within the Pterosauria is dramatically different in the various phylogenetic hypotheses. According to Wei et al. (2021) there are at least five main positions recovered for the clade and they add a sixth one. In some phylogenetic hypotheses, the Anurognathidae are the most basal pterosaurs (Kellner 2003; Lü \& Ji 2006; Bennett 2007; Wang et al. 2009, 2014, and 2017). They occur low in the pterosaur tree, although not in a basal position, in the phylogenetic hypotheses by Unwin (2003) and Lü et al. (2010a, 2012), while they are closer to the Pterodactyloidea according to other authors. They are the sister group of the Pterodactyloidea in the phylogenetic hypotheses by Dalla Vecchia (2009a, b) and Andres et al. (2010), but it must be considered that the wukongopterids were not included in these analyses because they were unknown before 2010 . Anurognathidae are nested within the Monofenestrata as the sister group of the Pterodactyloidea in the more recent phylogenetic hypotheses by Andres (2012), Andres \& Myers (2013), Andres et al. (2014) and Wu et al. (2017), while they are the basalmost monofenestratan in that of Wei et al. (2021). Britt et al. (2018) and Dalla Vecchia (2019) were the first to include 'Dimorphodon' weintraubi in their analyses; they found the anurognathids inclusive of 'Dimorphodon' weintraubi to be the sister group of a trichotomy of Sordes pilosus, Rhamphorhynchinae + Scaphognathus crassirostris, and Monofenestrata. According to Vidović \& Martill (2018), Anurognathidae are the sister group to Sordes pilosus + Sericipterus wucaiwaensis within Scaphognathinae sensu Unwin (2003); 'Dimorphodon' weintraubi is not included in this analysis.

Batrachognathus volans is an anurognathid pterosaur described by Ryabinin (1948) based on the holotype specimen "No. 52 - 2" (Ryabinin 1948: 87). According to Bakhurina \& Unwin (1995: tab. $1)$, the species is represented by two specimens; according to Unwin \& Bakhurina (2000: 423), they are the holotype PIN 52-2 and the undescribed PIN 2585/4a (which was found much later than the holotype and is preserved on the same slab surface as the holotype of the non-monofenestratan pterosaur Sordes pilosus described by Sharov 1971). Apparently, Unwin et al. (2000: tab. 2) reported measurements from a third specimen of Batrachognathus volans specimen (PIN 13), which has never been figured, described or reported elsewhere with this inventory number; this specimen is actually the holotype PIN 52-2 (see Bakhurina \& Unwin 1995: 216). The two specimens referred to $B a$ trachognathus volans come from the Upper Jurassic (Oxfordian-Kimmeridgian) Karabastau Formation (Karabastau Svita; Unwin \& Bakhurina 2000: 423) of the Karatau Ridge, Kazakhstan. Specimen PIN 52-2 includes the better preserved anurognathid skull reported to date, although it is slightly disar- 
ticulated and partially concealed by other skeletal elements. PIN 52-2 has been figured in Wellnhofer (1991: 101), Bakhurina \& Unwin (1995: fig. 8), Unwin \& Bakhurina 2000: fig. 21.3), and Hone (2020: fig. 5). The skull of PIN 2585/4a is complete and articulated, although it is not well preserved as PIN 52-2; it has been figured in Unwin (2006: fig. 5.3 lower left corner). Despite their importance in the understanding of the anurognathid skull morphology, these specimens have never been described in detail after the report of the holotype by Ryabinin (1948).

This paper deals with the reinterpretation of the orbital, antorbital and narial fenestrae of the anurognathid pterosaurs and its implications on the relationships of the anurognathids. The reinterpretation is based mainly on observations of the skulls of Batrachognathus volans.

Institutional abbreviations: CAGS, Chinese Academy of Geological Sciences, Beijing, China; MCSNB, Museo Civico di Scienze Naturali di Bergamo, Italy; MPUM, Museo Paleontologico del Dipartimento di Scienze della Terra dell'Università di Milano, Italy; NJU, Nanjing University, Nanjing, China; and PIN, Palaeontological Institute, Russian Academy of Sciences, Moscow, Russia.

\section{Materials AND MEthods}

PIN 2585/4a has been referred to Batrachognathus volans by several authors (e.g., Bakhurina \& Unwin 1995; Unwin \& Bakhurina 2000; Costa et al. 2013; Hone 2020; Wei et al. 2021), but the diagnostic features of the species, and genus by monotypy, listed by Hone (2020: 1688) have not been observed in this specimen. The referral of PIN 2585/4A to Batrachognathus volans must be considered provisional and essentially based on the same stratigraphic and geographical provenance as the holotype.

Details of the two specimens PIN 52-2 and PIN 2585/4A have been observed in the published figures (Wellnhofer 1991: 101; Bakhurina \& Unwin 1995: fig. 8; Unwin \& Bakhurina 2000: fig. 21.3; Hone 2020: fig. 5; and Unwin 2006: fig. 5.3) as well as some high resolution photographs showing different views and taken with different illumination. As the author of this paper is not the author of those photographs and did not get a formal permission to publish them, only the drawings traced based on them are reported here. Information about the other mentioned specimens derives only from the literature.

The "rostrum" is considered here the part of the skull anterior to the orbit and "rostral" refers to this part of the skull. As the rostral portion of the anurognathid skull is unusually short, I preferred to use here "anterior" and "posterior" instead of "rostral" and "caudal" in the description of the polarity of the cranial bones to avoid confusion. External naris and narial fenestra are considered as synonyms.

The first phylogenetic definition of the Anurognathidae was published by Unwin (2003: 176): Anurognathus ammoni, Batrachognathus volans, their most recent common ancestor, and all its descendants. This definition has priority and there would appear to be no need of an additional definition like that given by Hone (2020: 1681): all taxa more closely related to Anurognathus than Dimorphodon, Pterodactylus or Scaphognathus. However, Unwin's definition was formulated when only three anurognathid species were known and implies that taxa having the typical anurognathid bauplan (see below) would fall outside the Anurognathidae if they turned out to be more basal than Anurognathus ammoni and Batrachognathus volans. Under Unwin's definition, 'Dimorphodon' weintraubi would not be considered an anurognathid. Similarly, sensu Unwin (2003), Vesperopterylus lamadongensis would not be considered an anurognathid in the strict consensus tree by Lü et al. (2018), and Dendrorbynchoides curvidentatus would not be considered an anurognathid in the strict consensus tree obtained from the matrix of Dalla Vecchia (2019) modified according to the results of this paper (see below). To avoid problems, the definition of Hone (2020) was used in this paper. Of course, one could retain Unwin's definition of the Anurognathidae and use other names (e.g., Anurognathoidea or Anurognathiformes) for the more inclusive clades. However, naming new clades is beyond the scope of this paper. Furthermore, it is wiser to wait for a more exhaustive description of the available anurognathid specimens and an increase of the coded characters in matrices (hopefully leading to more stable results) before introducing new clade names.

The data matrix of Dalla Vecchia (2019) has been modified according to the results of this paper and then used to perform a parsimony-based phylogenetic analysis in PAUP 4.0b10 for Microsoft Windows (Swofford 2002) under the same conditions specified by Dalla Vecchia (2019). In the character state codings, specimen CAGS-Z070/CAGS-IG-02-81 (see below) has been considered as belonging to Jeholopterus ningchengensis, following Wei et al. (2021). Only Dendrorbynchoides curvidentatus has been coded instead of Dendrorbynchoides spp., because Dendrorbynchoides mutoudengensis was referred to the distinct genus Luopterus by Hone (2020). Character 17 "Jugal, rostrally expanded to overlap most of the maxilla laterally" has been eliminated. Changes can be traced in the modified matrix available as Supplementary Information. As no lagerpetid was added as outgroup in this analysis, the topology at the base of the strict consensus tree differs from that obtained by Ezcurra et al. (2020). However, this is irrelevant to the purpose of this paper.

The Nexus data matrix used by Wei et al. (2021: https:// dfzljdn9uc3pi.cloudfront.net/2021/11161/1/Wei_et_al_2021_ Sinomacrops_bondei.nex) to produce the strict consensus tree of Wei et al. (2021: fig. 7) has also been modified according to the results of this paper (see SI) and then used to perform a parsimony-based phylogenetic analysis in TNT 1.5 (Goloboff \& Catalano 2016) under the same conditions specified by Wei et al. (2021). Character states regarding the jugal, maxilla, premaxilla and skull fenestrae in the anurognathid taxa have been coded consequently. No new characters have been added and characters and character states have not been controlled for correction if wrong, ambiguous, poorly-formulated and redundant. My purpose was not the improvement of the data matrix, but only checking the impact of the changes in character codings according to the results of this paper on the relationships between the Anurognathidae and the other pterosaurs. Anyway, some problems have been encountered. For example, the numbers of the characters mentioned in the text of Wei et al. (2021) do not correspond with the character numeration in the matrix. Wei et al. (2021: 27) mention "Character 95 (1). Jugal, lacrimal process, subvertical", but this is character 91 in the Nexus matrix. Character 21 presents three states ( 0 to 2 ) in its definition, but the same character has four character states in the matrix (0 to 3). Six characters of the matrix are constant and 52 variable characters are parsimony-uninformative; thus, the parsimony-informative characters are 320 out of 378 . 


\section{Previous reconstructions of the ANTERIOR SKULL FENESTRAE IN THE ANUROGNATHIDS}

The first anurognathid to be described by Döderlein (1923), Anurognathus ammoni, had an incomplete and poorly preserved skull, which was tentatively reconstructed by Wellnhofer (1975b: fig. 38b) as that of the non-monofenestratan pterosaurs, with distinct narial, antorbital and orbital fenestrae, the rounded antorbital fenestra being the largest.

The skull of Anurognathus ammoni was reconstructed in a different way by Bennett (2007), based on a second, complete and articulated specimen of this pterosaur, which is represented by slab and counterslab kept separately in two private collections in Germany. The skull of this specimen is exposed in dorsal view flattened dorsoventrally; it is relatively complete and articulated but not well preserved (Bennett 2007: fig. 3). The incomplete, crushed and broken cheek bones of that skull are difficult to interpret; Bennett (2007: 380) tentatively identified a left maxilla in dorsal view overlapped laterally by the jugal and preserving a row of three teeth in its midline (Bennett 2007: fig. 3). A slender and sigmoid skeletal element that "arises from the anterior end of the body of the jugal in contact with the maxilla" is reported as the "ascending process of the jugal" and "ascending process of the jugal plus the lacrimal and nasal" in the text (pp. 381 and 382, respectively), while it is identified as the "jugal/nasal process" in figure 3. Based mainly on this second specimen, Bennett (2007: fig. 4) reconstructed the skull of Anurognathus ammoni with an anteriorly extended jugal that overlays the maxilla laterally fusing with it, with the exclusion of the anteriormost portion of the maxilla that articulates with the premaxilla. This anteriormost portion has a thin ascending process separating the narrow antorbital fenestra from the external naris. In this reconstruction, the ascending process of the jugal separates the enormous orbit from the narrow antorbital fenestra.

Andres (2010) coded as "unknown" (?) the presence/absence of a nasoantorbital fenestra in Batrachognathus volans and others anurognathids in the matrix of his analysis, but Andres et al. (2010, 2014) coded "confluent external naris and antorbital fenestra" as present in Jeholopterus ningchengensis and Batrachognathus volans. Andres et al. (2010: 187) were the first to opt for this coding because they observed that the thin ascending process of the maxilla of Bennett's reconstruction is doubtfully present in Anurognathus ammoni and absent in specimens PIN 13 and PIN 2585/4 of Batrachognathus volans and in a specimen (CAGS-Z070/CAGS-IG-02-81) figured by Ji \& Yuan (2002) and referred to Jeholopterus. The nasoantorbital fenestra was coded as present in the four anurognathid species included in the analysis by Vidović \& Martill (2018). The nasoantorbital fenestra was coded as present in Jeholopterus ningchengensis, Anurognathus ammoni and Batrachognathus volans also in the phylogenetic analysis by Britt et al. (2018) and Dalla Vecchia (2019); although this coding was not explained by these authors, they independently did it for the same reason adduced by Andres et al. (2010).

Hone (2020: 1681) considered as "heterodox scorings of character states" the identification of a "confluent nasoantorbital" fenestra by Andres et al. (2010, 2014), ignored the scorings by Vidović \& Martill (2018), Britt et al. (2018) and Dalla Vecchia (2019), and preferred the reconstruction by Bennett (2007) of narrow and distinct narial and antorbital fenestrae. With Hone's (2020: 1683) words: "Naris [in anurognathids] is dorsoventrally tall though anteroposteriorly short and sits at the very anterior margin of the skull. Antorbital fenestra similar in appearance and separated from the naris anteriorly and the orbit posteriorly by only thin splints of bone. Orbit is extremely large and occupies approximately half of the lateral face of the skull".

Wei et al. (2021: 11) also supported the presence of a nasoantorbital fenestra in the anurognathids for the same reason as Andres et al. (2010). Following Bennett (2007), they considered the process separating the orbit from the single rostral fenestra as the lacrimal process of the jugal, bone which is supposed to be laterally fused with not visible sutures to the maxilla to form a "jugo-maxilla" making most of the jaw.

\section{Systematic Palaeontology}

DIAPSIDA Osborn, 1903

Pterosauria Kaup, 1834

Anurognathidae Kuhn, 1967 (ex Anurognathinae Nopcsa, 1928) sensu Hone (2020) 
Batrachognathus Ryabinin, 1948

\section{Batrachognathus volans Ryabinin, 1948}

\section{Description and comparison}

The skull and mandible of the holotype of $B$. volans (PIN 52-2; Fig. 1) are dorsoventrally crushed and flattened. They are exposed in ventral view and slightly disarticulated, with the mandible partly overlapping the upper jaw. Despite this, the anterior cranial elements and the mandible of PIN 52-2 are by far the best preserved among the anurognathids. This skull is better preserved than that of the second specimen of Anurognathus ammoni used by Bennett (2007) for the reconstruction of the skull of that species, taken since then as reference for the anurognathid skull morphology. With respect to the second specimen of Anurognathus ammoni, the main anterior skull elements of PIN 52-2 are better preserved and exposed and do not need to be interpreted.

The description and review of the entire skull of PIN 52-2 is beyond the scope of this paper; this will hopefully be done by someone else with the specimen at hand. I will focus here only on the anterior skull fenestrae and the skeletal elements surrounding them.

The premaxillae of PIN 52-2 are strongly appressed against each other but not fused (the suture is still visible) forming a T-shaped bone as characteristic of anurognathids. Each premaxilla is composed of a small main body and two processes. The posterodorsal process is relatively broad at the base, but it tapers distally; it is mostly concealed by the overlap and juxtaposition of other skull elements, probably including the vomers. The posterolateral process has a trapezoidal outline, with a tapering posterior end where a corresponding process of the adjacent bone overlapped dorsally. The ventral margin of each premaxilla bears slender and recurved teeth, which are in number of three according to Ryabinin (1948). The bones that are posterolaterally adjacent to the joint premaxillae are slightly shifted posteriorly from their anatomical articulation with the premaxillae; only the anterior end is visible of the right one, because the rest is covered by some limb bones, whereas the left one is better exposed. The latter shows its medioventral aspect because of crushing and is partially overlapped posteriorly by the left mandibular ramus. This large element ad- jacent to the maxilla is triradiate. Its anterior ramus is very short and clearly overlapped the tapering posterolateral process of the left premaxilla dorsally. The dorsal ascending ramus is nearly vertical, long and narrow. Its dorsal end is covered by other skeletal elements; it appears to expand slightly mediolaterally toward the apical part. The posterior ramus is by far the largest of the three; it is strap-like, slightly tapering posteriorly and slightly arched dorsally and medially. The dorsomedial margin of the distal portion of this ramus is overlapped by the left mandibular ramus; the distal end appears to be cut and blunt. Ventrally, along the lateral margin, this longest ramus bears a row of teeth (eight teeth, according to Ryabinin 1948). The row extends at least along $59 \%$ of the ventral margin of the bone. Teeth appear to be similar in shape and size to the premaxillary ones. This triradiate element includes the left maxilla because of its spatial relationships with the premaxilla and the fact that the only tooth bearing upper jaw bones are the premaxilla and maxilla in reptiles (Romer 1956). In fact, Ryabinin (1948: fig. 1) had identified this element as the left maxilla. The short anterior ramus is the premaxillary process of the maxilla and the vertical ramus corresponds to the ascending process of the maxilla. When articulated, the premaxillary process of the maxilla and the maxillary process of the premaxilla form a bar that borders ventrally the external naris. The posterior ramus is plausibly formed by the fusion of the jugal process of the maxilla with the maxillary process of the jugal as occurs in other pterosaurs and probably includes also the body of the jugal, as suggested also by its length with respect to the mandibular ramus. Therefore, the element is a maxillojugal. In Caelestiventus hanseni (see Britt et al. 2018: fig. 3h-i and personal observation) and Seazzadactylus venieri (see Dalla Vecchia 2019: fig. 7A) the jugal overlaps the jugal process of the maxilla laterally, forming the bar that borders the antorbital fenestra ventrally. The jugal may remain unfused to the maxilla, as it is the case of Seazzadactylus venieri, or be fused to form a maxillojugal as in Caelestiventus banseni. In the latter taxon, the suture between the jugal and the maxilla is obliterated, whereas the premaxillae are not fused to the maxillae and the dentaries are not fused at the symphysis, like in PIN 52-2. The anterior extent of the overlap of the jugal on the maxilla, if visible, may not be established in PIN 52-2, because the posterodorsal part of the 


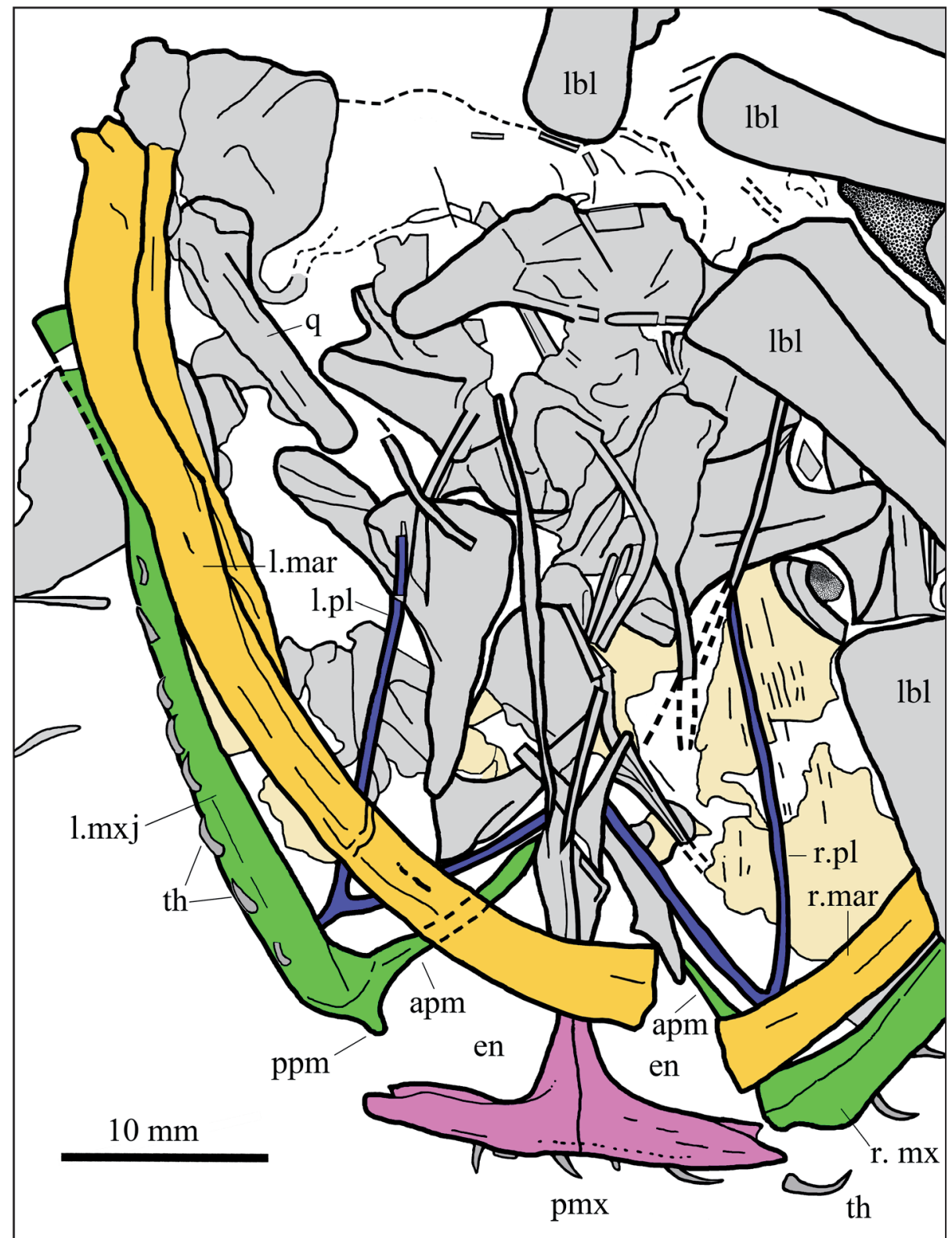

Fig. 1 - Batrachognathus volans, PIN 52-2, holotype, skull and lower jaw in ventral view. Interpretative drawing. The clearly identifiable portion of the premaxilla is marked in fuchsia, the maxillojugals in green, the palatine/ ectopterygoids in blue, and the mandible in orange. The other bones are in gray colour, teeth in dark gray and patches of soft tissue are in pale yellow. The margins of the bones or portions of bone that are preserved only as an impression are represented by dashed lines.

Abbreviations: apm, ascending process of the maxilla; en, external naris (narial fenestra); l, left; lbl, long bone of the limbs; mar, mandibular ramus; mx, maxilla; mxi, maxillojugal; pl, palatine/ ectopterygoid; pmx, premaxillae; ppm, premaxillary process of the maxilla; $\mathrm{q}$, quadrate; r, right; th, tooth. Scale bar $=10 \mathrm{~mm}$.

maxillojugal is concealed by the overlapping mandibular ramus. Regardless, there is no evidence that the jugal extended as far anteriorly as hypothesized by Bennett (2007) for Anurognathus. The jugal does not totally cover the maxilla laterally, because the teeth are set on the lateral edge of the maxillojugal, which is consequently formed by the maxilla only. Therefore, there is no reason to assume that the single ascending process of the maxillojugal is an anteriorly migrated lacrimal process of the jugal. In all non-monofenestratan pterosaurs the bar separating the external naris from the immediately posterior opening (the antorbital fenestra) is the ascending process of maxilla. Instead, in PIN 52-2 there is no evidence of a jugal-lacrimal bar, formed by the anterodorsal (lacrimal) process of the jugal and the lacrimal, separating the orbit and the antorbital fenestra. Only a single large opening occurs posterior to the ascending process of the triradiate bone.

Unfortunately, the crushed, slightly disarticulated, and only partly preserved posterior part of the skull gives no information about the temporal fenestrae and their separation from the orbit. A postorbital cannot be identified and the rod-like straight bone contacting the posterior part of the left mandibular ramus is probably the left quadrate.

Other unambiguously identifiable skull bones in PIN 52-2 are the filiform and forked elements characteristic of the anurognathid palate, which have been identified as the palatine/ectopterygoids by Bennett (2007: fig. 5). Despite the crushing of 
the skull, the palatines/ectopterygoids are still located in correspondence to their medial articulation with the maxilla just posterior to the ascending process.

The skull of PIN 2585/4A (Fig. 2) is articulated, probably exposed in dorsal view and flattened dorsoventrally. The skull overlaps the mandible, but the left mandibular ramus is slightly rotated to the right with respect to the upper jaw and is thus not totally concealed by the upper jaw and is partially visible in dorsal view. Most of the posterior part of the skull probably remained on the counterslab or split away and is not preserved on this slab. Because of the articulation of the cranial bones, the strong crushing, and the partial overlapping of upper and lower jaws, it is difficult to distinguish between mandible and premaxillae + maxillojugals. However, the anterior skull fenestrae are unambiguously identifiable. It is evident that there are only two large anterior fenestrae in this skull: a rostral D-shaped narial fenestra bordered posteriorly by the ascending process of the maxilla and an enormous posterior fenestra which is undivided and reaches very posteriorly in the skull. There is no evidence of a jugal-lacrimal bar in the lateral side of the skull. Missing the posterior part of the skull, there is no information on the temporal openings and the posterior end of the orbit. Two slender and straight bone impressions may represent the right postorbital and right quadrate given their position, but nothing can be said about their morphology. The ascending process of the left maxilla has a lanceolate shape and appears to be slightly disarticulated from a slender element that probably overlapped it posteriorly, descending from the median dorsal bar of the skull. Because of crushing, this latter element partly overlaps a ramus of the forked palatine/ectopterygoid; similarly, on the right side, a ramus of the right palatine/ectopterygoid is contiguous with the ascending process of the maxilla. The element posterior to the ascending process is possibly preserved also in the right side of the skull, slightly disarticulated from its anatomical position (Fig. 2). That element may be the nasal as suggested for Anurognathus by Wellnhofer (1975b: fig. 38b), but the nasal is usually placed anterior or anterodorsal to the ascending process of the maxilla in the reconstructions of the early pterosaurs (Wellnhofer 1978: fig. 2; Sangster 2003: fig. 2.2; Padian 2008a: fig.18; Padian 2008b: fig.10; Cheng et al. 2012: fig. 5; Bennett 2014: figs.

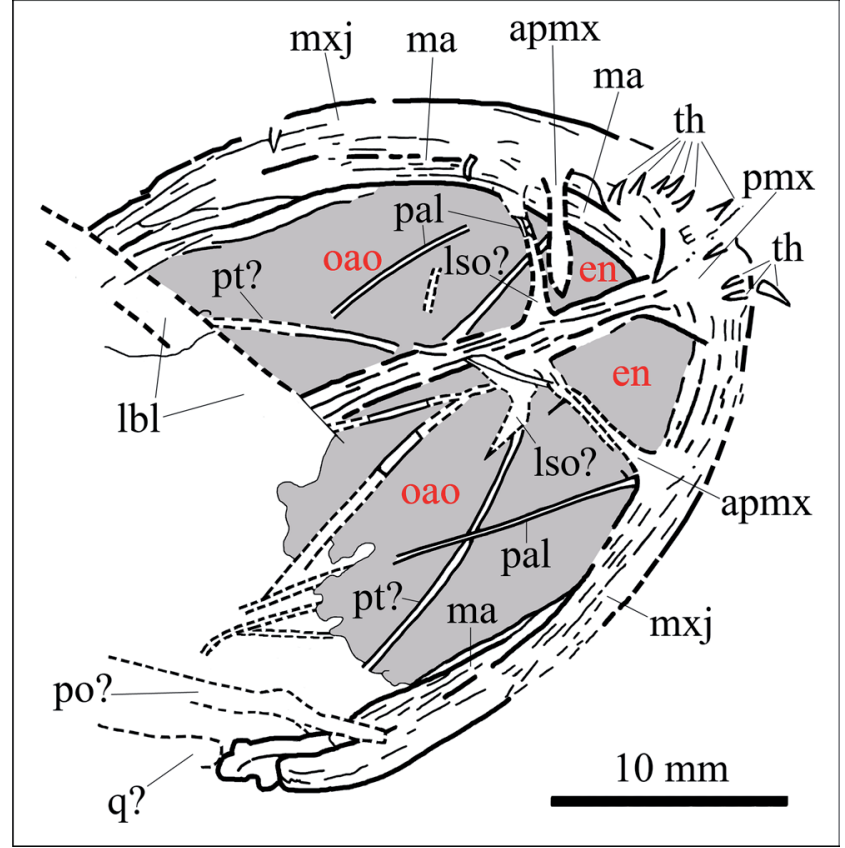

Fig. 2 - Batrachognathus volans, PIN 2585/4A, skull and lower jaw in dorsal view. Interpretative drawing. Bones that are probably preserved only as an impression are represented by dashed lines. The two anterior skull openings are evidenced with grey colour.

Abbreviations: apmx, ascending process of the maxilla; en, external naris (narial fenestra); lbl, long bone of the limbs; lso, lacrimal or supraorbital; ma, mandible; mxj, maxillojugal; oao, orbitoantorbital fenestra; pal, palatine/ectopterygoid; po, postorbital; pt, pterygoid; pmx; premaxilla; q, quadrate; and th, tooth. Scale bar $=10 \mathrm{~mm}$.

2 and 5A; Zhou 2014: fig. 5). Alternatively, it could be the lacrimal, whose anatomical position is at the anterior margin of the orbit and was located above the maxilla in basal reptiles (Romer 1956), or the supraorbital. The lacrimal or supraorbital would have migrated anteriorly, overlapping the ascending process of the maxilla posteriorly and medially.

Unlike Anurognathus (see Bennett 2007), there is no evidence of the sclerotic ring elements in the orbits of the two Batrachognathus specimens.

\section{Discussion}

\section{The anterior skull fenestrae in the anurognathid skull}

In his reconstruction of the skull of Anurognathus ammoni, Bennett (2007) drew a thin ascending process of the maxilla separating the external naris from the antorbital fenestra. As seen above, evidence of this division of the rostral fenestra is lacking in the holotype of Anurognathus ammoni, ambiguous in the second specimen and absent in other 
anurognathid specimens; this has been remarked in most of the recent papers dealing with the subject. The specimens of Batrachognathus volans present a D-shaped narial fenestra anterior to the ascending process of maxilla and a single much, larger fenestra posterior to the ascending process of maxilla which is formed by the confluence of orbit and antorbital fenestra.

The features observed in the two Batrachognathus specimens occur also in an articulated anurognathid skull from China figured in Ji \& Yuan (2002: figs 1 and 2A) and reported as CAGS-Z070 by Yang et al. (2019: fig. 1b, SI fig. 3A) but referred to as CAGS-IG-02-81 by Hone (2020: fig. 3B) and Wei et al. (2021: fig. 13). This specimen is figured also in Unwin (2006: fig. 11.1) and Lü et al. (2006: figs 3.5 and 3.6). It was mentioned by Andres et al. (2010) regarding the absence of a vertical bar dividing the rostral skull opening. It has been referred to Jeholopterus ningchengensis by Lü et al. (2006), Hone (2020) and Wei et al. (2021), but is identified as an indeterminate anurognathid by Yang et al. (2019). It comes from the Middle-Upper Jurassic of the Daohugou locality of China (Yang et al. 2019). The skull of this specimen appears to be relatively well-preserved (see Lü et al. 2006: figs 3.6; Wei et al. 2021: fig.13), but it has not yet been described in detail. The published photos and drawings by Lü et al. (2006: figs 3.5-6) and Yiang et al. (2019: SI fig. 1B), and description and drawing by Wei et al. (2021: Fig. 13B) are in agreement with the observations made on Batrachognathus specimens: the ascending process of maxilla separates the $\mathrm{D}$-shaped external naris from a single large fenestra made by the orbit plus the antorbital fenestra and is the only ascending process identifiable laterally on the skull, and the forked palatine/ectopterygoid join the maxilla medially in correspondence of the base of the ascending process. Also in this case, the posterior portion of the skull appears to be poorly preserved as in the two Batrachognathus specimens and the sclerotic ring elements may be missing.

Given the peculiar skull shape shared by all anurognathids (excluded possibly 'Dimorphodon' weintraubi) and the conservatism of anurognathid anatomy in general (Hone 2020), it is likely that the orbitoantorbital fenestra is synapomorphic of all anurognathids (with the possible exception of 'Dimorphodon' weintraubi), unless evidence appears to the contrary.

\section{Evolution of the anterolateral skull fenestrae in the pterosaurs}

In the earliest non-monofenestratan pterosaurs (Fig. 3A), the external naris, antorbital fenestra and orbit are distinct openings, which is the plesiomorphic condition of the Archosauriformes (Nesbitt 2011). The external naris is bordered anteriorly and dorsally by the premaxilla, ventrally by the premaxillary process of the maxilla and in some taxa also by the maxillary process of the premaxilla (which never extends beyond the anterior half of the margin, anyway), posteriorly by the ascending process of the maxilla and posterodorsally by the nasal. The antorbital fenestra is bordered anteriorly by the ascending process of the maxilla, ventrally by the bar composed of the jugal process of the maxilla and the maxillary process of the jugal, posteriorly by the bar formed to a variable extent by the anterodorsal (lacrimal) process of the jugal and the lacrimal, and dorsally by the ascending process of the maxilla (anteriorly) and the lacrimal (posteriorly). In some taxa, like Dimorphodon macronyx, the nasal may have participated to the anterodorsal margin of the antorbital fenestra (see reconstruction by Sangster 2003: fig. 2.1A). The orbit is bordered anteriorly by the jugal-lacrimal bar separating it from the antorbital fenestra, ventrally by the jugal, posteriorly by the postorbital and by the postorbital rami of jugal and frontal, dorsally by the frontal, and anterodorsally by the supraorbital.

In later non-monofenestratan pterosaurs, like Angustinaripterus and Scaphognathus (Fig. 3B), the premaxilla is excluded from the ventral and anterior margin of the external naris and the anterior end of the opening is bordered by an anterodorsal process of the premaxillary process of the maxilla.

In monofenestratan pterosaurs (Fig. 3C), the external naris and antorbital fenestra are confluent forming a nasoantorbital fenestra because of the disappearance of the ascending process of maxilla, apparently starting from a maxillary morphology like that in Figure 3B (i.e., that bearing an anterodorsal process on the premaxillary process). The elongation of the rostrum anterior to the antorbital fenestra and the enlargement of the external naris produced a corresponding elongation of the narial contribution to this composite fenestra. The nasal still sends a long anteroventral process into the nasoantorbital fenestra in basal Monofenestrata (e.g., Darwinopterus; Lü et al. 2010a) and basal Pter- 
Fig. 3 - Skull reconstructions and fenestration patterns of earlydiverging non-monofenestratan, monofenestratan and anurognathid pterosaurs. A) The basal Triassic pterosaur Seazzadactylus venieri; B) the basal Late Jurassic pterosaur Scaphognathus crassisrostris; C) the basal monofenestratan Darwinopterus modularis; D) the anurognathid Batrachognathus volans. A is from Dalla Vecchia (2019), modified; B is redrawn from Wellnhofer (1975b) and modified according to Bennett (2007); C is redrawn and modified from Lü et al. (2010a); D is based on the reconstruction of the skull of Anurognathus by Bennett (2007) and modified according to morphology of the anterior part of the skull shown in the two specimens of Batrachognathus volans. In figure D, the shape of the frontal and the posterior part of the skull, included the temporal fenestrae, are those hypothesized for Anurognathus by Bennett (2007), because they cannot be reliably reconstructed in Batrachognathus. As all anurognathid skulls are flattened and quadrates and postorbitals are poorly or not preserved, the depth of the skull is hypothetical in figure D. Also mandibular teeth are hypothetical in figure D.

Abbreviations: eaof, antorbital fenestra; en, external naris (narial fenestra); fr, frontal, j, jugal; lac, lacrimal; ltf, lower temporal fenestra; mx, maxilla; na, nasal; nao, nasoantorbital fenestra; or, orbit (orbitoantorbital fenestra in Batrachognathus volans); pmx, premaxilla; so, supraorbital, utf, upper temporal fenestra. Not drawn to scale.

odactyloidea (e.g., Germanodactylus and Pterodactylus; Wellnhofer 1970), which nearly disappeared in later pterodactyloids (e.g. Pteranodon; Bennett 2001).

In the anurognathids, the modification of the snout is the opposite to that of the Monofenestrata. The shortening of the rostrum is obtained by the extreme anteroposterior curtailment of the premaxillary body and of the premaxillary process of maxilla. The jaws arched laterally, forming the unique, short and broad anurognathid skull morphology. The external naris is resultedly deeper than long and bordered ventrally mainly by the premaxilla, unlike all other pterosaurs. The bar separating the orbit and the antorbital fenestra disappeared, forming a large orbitoantorbital fenestra. This was attained by the loss of the anterodorsal (lacrimal) process of the jugal; the lacrimal was also lost or migrated anteriorly following the verticalization of the ascending process of maxilla. Alternatively, the lacrimal was lost with the anterodorsal (lacrimal) process of the jugal and the bone posterior to the ascending process of maxilla is the anteriorly shifted supraorbital. It is worth note that, according to the reconstruction of the skull of Anurognathus ammoni by Bennett (2007) used as the base for the tentative reconstruction of the Batrachognathus volans skull of Figure 3D, the postorbital process of the jugal is also lost in the anurognathid skull and the
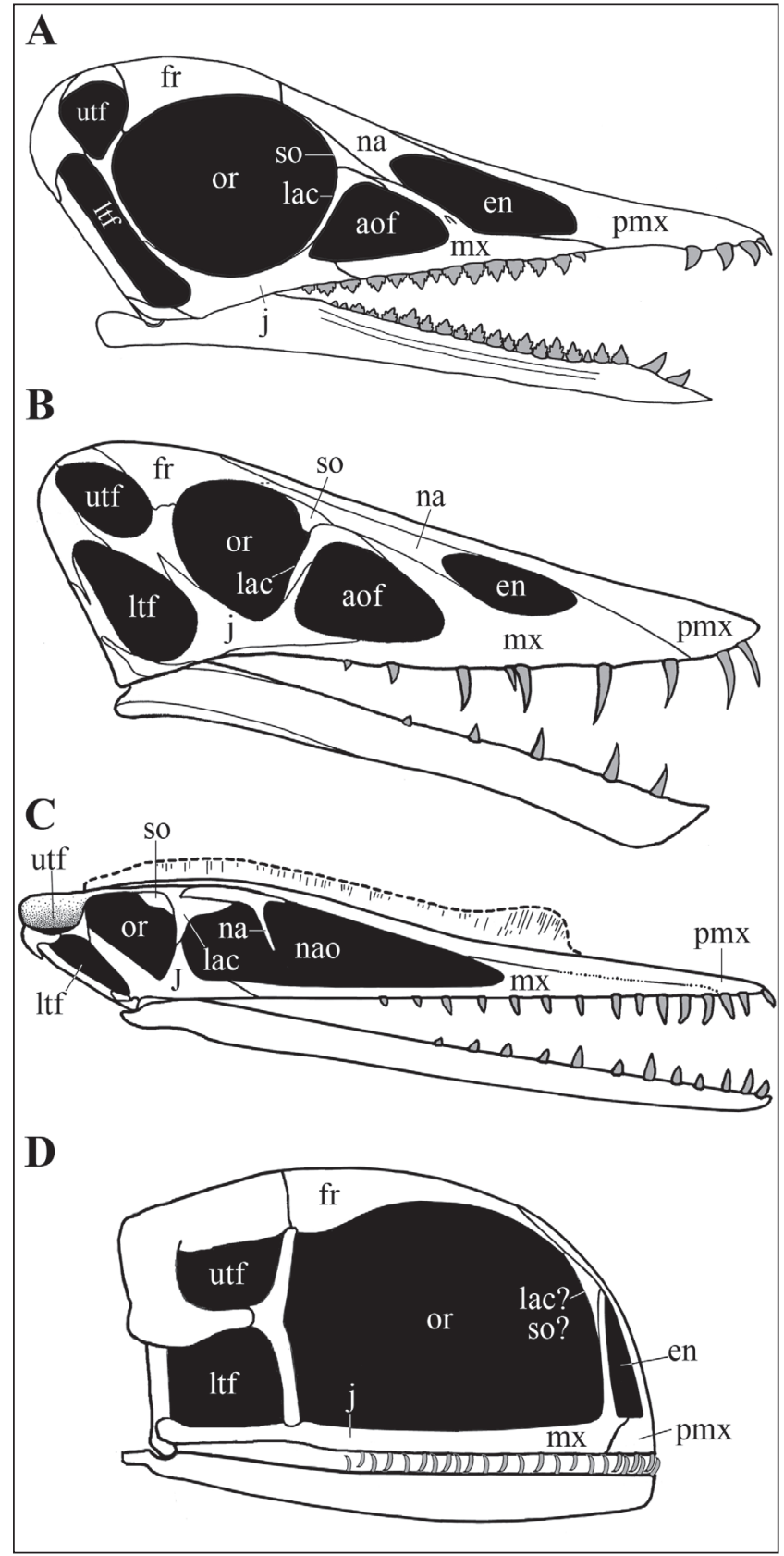

postorbital articulates directly with the body of the jugal. Therefore, the jugal may be simply a horizontal anteroposterior bar overlapping the jugal process of the maxilla to an unknown anterior extent and bordering the orbitoantorbital fenestra. The loss of the jugal-lacrimal bar would have allowed for the expansion of the orbital space leading to the development of an enormous eye.

\section{Phylogenetic analysis}

The data matrix of Dalla Vecchia (2019) (see Materials and Methods section) has been modified for the characters regarding the external naris, an- 


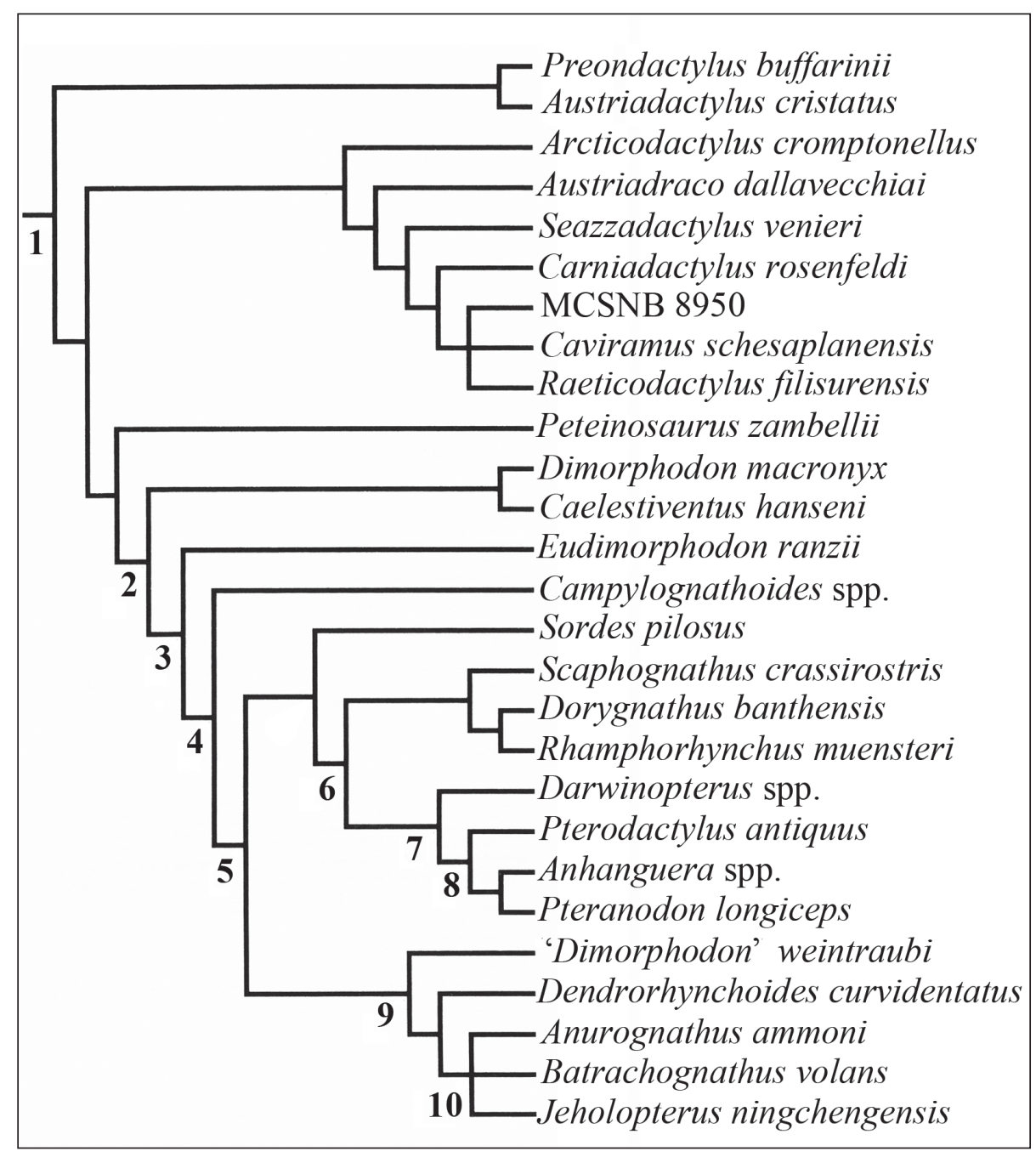

Fig. 4 - Phylogenetic position of the Anurognathidae based on the modified matrix of Dalla Vecchia (2019). Strict consensus tree of nine most parsimonious trees as computed in PAUP 4.0b10 (length $=281$ steps, $\mathrm{CI}=$ $0.5587, \mathrm{RI}=0.6923)$.

Legend: 1, Pterosauria; 2, Macronychoptera; 3, Lonchognatha; 4, Novialoidea; 5 , Caelidracones; 6, Breviquartossa; 7, Monofenestrata; 8, Pterodactyloidea; 9, Anurognathidae (sensu Hone 2020); 10, Anurognathidae (sensu Unwin 2003).

torbital fenestra, orbit, premaxilla, maxilla and jugal in the anurognathids, according with the results of this paper. In the resulting strict consensus tree of nine most parsimonious trees, the Anurognathidae are the sister group of Sordes pilosus + Breviquartossa (Fig. 4). With respect to the strict consensus tree of Dalla Vecchia (2019), the trichotomy between Sordes pilosus, Scaphognathus crassirostris + Rhamphorhynchinae and Monofenestrata is resolved, while the relationships within the Anurognathidae are less resolved and Dendrorbynchoides curvidentatus results more basal than Anurognathus ammoni and Batrachognathus volans. The clade Dendrorbynchoides curvidentatus + Anurognathidae sensu Unwin (2003) corresponds to the Asiaticognathidae of Kellner (2003).

However, the matrix by Dalla Vecchia (2019) was made to investigate the relationships of the earliest (Triassic) pterosaurs, not those of the anurognathids (it includes only Anurognathus ammoni, $\mathrm{Ba}$ trachognathus volans, Dendrorbynchoides curvidentatus and Jeholopterus ningchengensis). Thus, 38 characters out of
$378(10 \%)$ have been revised based on the results of this paper in the matrix by Wei et al. (2021), which is the most recently published matrix, includes seven anurognathid taxa and was specifically constructed to investigate the anurognathid relationships (both internal and with other pterosaur clades). Information about the modified character states is included in the Supplementary Information. The goal of this revision is to investigate the impact that the presence of an orbitoantorbital fenestra in the anurognathid skull has in the strict consensus tree produced running the modified matrix. The goal is not to produce a phylogenetic hypothesis alternative to that of Wei et al. (2021). Therefore, the presence of an orbitoantorbital fenestra, a distinct narial fenestra, an ascending process of maxilla, and the absence of a jugal-lacrimal bar have been coded for all anurognathid taxa under the assumption of the conservatism of anurognathid cranial anatomy postulated by Hone (2020), even when the character states are not actually observed in some taxa. 


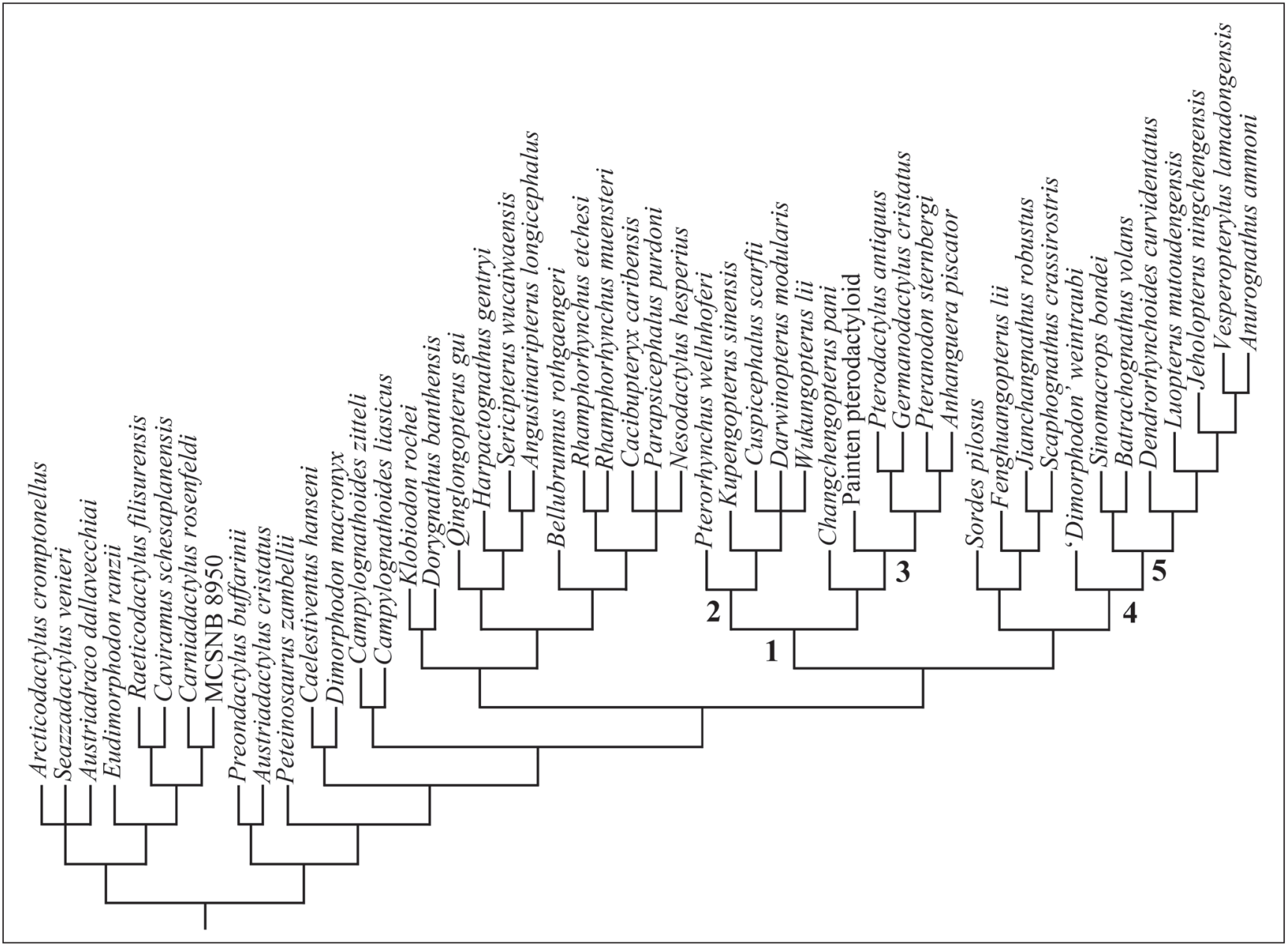

Fig. 5 - Phylogenetic position of the Anurognathidae based on the modified matrix of Wei et al. (2021). Strict consensus tree of two most parsimonious trees as computed in TNT 1.5 (length $=1110$ steps, CI $=0.4541$ [CI excluding uninformative characters $=0.4250$ ], RI $=0.6735$. Legend: 1, Monofenestrata; 2, Darwinoptera; 3, Pterodactyloidea; 4, Anurognathidae sensu Hone (2020); 5, Anurognathidae sensu Unwin (2003).

The formulation of most of the characters regarding external naris, antorbital fenestra, orbit, nasoantorbital fenestra, maxilla and jugal done by Wei et al. (2021) makes them "inapplicable" for anurognathids. This is somewhat problematic, because "inapplicable" characters are not treated as such by TNT, but are practically considered as codifiable but "unknown". Furthermore, the states of characters regarding the nasal and the lacrimal have been considered as unknown because the presence and position of these elements is still to be confirmed in the anurognathids. This decreased the number of codified characters for the anurognathids.

The analysis found two most parsimonious trees like that by Wei et al. (2021); in the resulting strict consensus tree (Fig. 5; five steps shorter than that by Wei et al. 2021), the Anurognathidae sensu Hone 2020 are the sister group of the clade Sordes pilosus + Fenghuangopterus lii + (Jianchangnathus robustus + Scaphognathus crassirostris). The clade Anurognathidae sensu Hone $2020+$ (Sordes pilosus + Fenghuangopterus lii + (Jianchangnathus robustus + Scaphognathus crassirostris)) is the sister group of the Monofenestrata.

Thus, the presence of an orbitoantorbital fenestra in the anurognathids (excluding 'Dimorphodon' weintraubi), based on the identification of the maxilla instead of the jugal as the bone bearing the ascending process separating the two anterior skull fenestrae, has an impact in the position of the Anurognathidae in the cladogram.

Because the Monofenestrata are defined as a synapomorphy-based clade by Andres et al. (2014: SI), i.e. "Monofenestrata after Lü et al. (2010)..., the most inclusive clade exhibiting confluent external naris and antorbital fenestra synapomorphic with that in Pterodactylus antiquus Soemmerring 1812", 
the presence of an orbitoantorbital fenestra would place Anurognathidae outside Monofenestrata by definition.

The single specimen of 'Dimorphodon' weintraubi preserves only the portion of the skull posterior to the orbits, which has not been described yet (Clark et al. 1994, 1998). Thus, we do not know whether this taxon had an 'anurognathid' skull or not and whether the 'anurognathid' skull is a feature of the Anurognathidae sensu Hone 2020 or of a less inclusive clade.

The matrix presents many unknown character state codings that could be codified after an adequate study of the specimens of Batrachognathus volans, Jeholopterus ningchengensis, other still unpublished Chinese anurognathid specimens, and 'Dimorphodon' weintraubi.

\section{The unique anurognathid bauplan}

There is a general agreement that the Anurognathidae are a distinct and peculiar group among the pterosaurs (Bennett 2007; Hone 2020; Wei et al. 2021). Anurognathids share with other non-pterodactyloid pterosaurs a digit $\mathrm{V}$ of the pes composed of two elongated phalanges (with the exclusion of Campylognathoides, which has a somewhat reduced pedal digit V; Padian 2008b) and a short wing metacarpal. Digit V of the pes is reduced in all pterodactyloids and the wing metacarpal (metacarpal IV) is proportionally more elongated than in non-pterodactyloid pterosaurs ("pes digit $\mathrm{V}$ with a single phalanx or entirely absent" and "wing metacarpal at least $80 \%$ the length of the humerus" are synapomorphies of the Pterodactyloidea according to Unwin 2003). The "elongation of the metacarpus is the diagnostic apomorphy of the Pterodactyloidea" according to Andres et al. (2014: 1015) and "referral to the Pterodactyloidea requires only that the wing metacarpal be longer than $80 \%$ of the humeral length" (Andres et al. 2014: Supplemental Experimental Procedures).

Anurognathid diagnostic features have been reviewed and discussed by Bennett (2007), Andres et al. (2010), and Hone (2020).

Skull and mandible. The most apparent feature of the anurognathid bauplan is the short and broad skull, which has a hemicircular to nearly circular outline in dorsal and ventral views and a very short rostrum with T-shaped premaxillae. The skull is broader than long (as in the reconstruction of
Anurognathus by Bennett 2007: fig. 4A) or about as long as broad (as in Batrachognathus PIN 2585/4A) and the jaws are broadly arching laterally (Wei et al. 2021: figs. 8-9). Height is the shortest skull dimension, thus the skulls of these pterosaurs are usually preserved in dorsoventral view and are reminiscent of those of frogs (the name Batrachognathus means "frog jaw"). Unlike other pterosaurs, the skull is comparatively small with respect to body size, especially in largest and probably more mature individuals. This is evident in the holotypes of Jeholopterus ningchengensis (see Wang et al. 2002) and Vesperopterylus lamadongensis (see Lü et al. 2018); the small size of the skull is independent from the extreme reduction of the rostrum.

The unique fenestration pattern, with an enormous orbitoantorbital and a much smaller and D-like external naris, is further evidence of the distinction of the skull bauplan of this clade from that of all other pterosaurs.

The structure of the palate is also distinctive of the anurognathids (Bakhurina 1988; Bennett 2007). The palatines/ectopterygoids, branched vomers and quadrate ramus of the pterygoid and/ or pterygoid ramus of the quadrate, according to the reconstruction by Bennett (2007), are slender, splint- or rod-shaped bones with a peculiar morphology that is not observed in any other pterosaur (Wellnhofer 1978; Ösi et al. 2010). In particular, the palatine/ectopterygoid is characteristically forked. These palatal elements are more or less preserved in Anurognathus ammoni, Batrachognathus volans, Dendrorbynchoides curvidentatus, Jeholopterus ningchengensis, and Luopterus mutoudengensis (fide Lü \& Hone 2012).

Other features that have been considered diagnostic of the anurognathids are somewhat ambiguous, not universally accepted or occur also in other pterosaur taxa.

Cervical ribs and vertebrae. Mid-cervical ribs (i.e., ribs of cervical vertebrae 3-7) are absent in juvenile Anurognathus ammoni (the first seven cervicals lack ribs; Bennett 2007) and in the only specimen of Vesperopterylus lamadongensis (no cervical ribs are associated with the preserved cervical vertebrae; Lü et al. 2018); the complete loss of mid-cervical ribs is a synapomorphy of Anurognathus ammoni and Vesperopterylus lamadongensis according to Wei et al. (2021). Dendrorbynchoides curvidentatus may lack cervical ribs (Unwin et al. 2000: fig. 2); Ji \& Ji (1998) and Unwin et al. (2000) do not mention them in their descrip- 
tion of the specimen. "Short and slender cervical ribs" are reported in Jeholopterus ningchengensis (see Wang et al. 2002: 227). Cervical ribs are not mentioned in the description of Sinomacrops bondei by Wei et al. (2021). No information is available about the cervical ribs of Batrachognathus volans and Luopterus mutoudengensis. In all these taxa, the cervical vertebrae are poorly preserved, but they appear to be short and stocky. Also the preserved cervicals of 'Dimorphodon' weintraubi are short and stocky (Clark et al. 1998). "Cervical vertebrae short and robust" is a diagnostic feature of the Family Anurognathidae according to Bennett (2007: 395). No vertebral feature is considered characteristic of the Anurognathidae by Hone (2020).

Earliest non-monofenestratan pterosaurs have long and filiform cervical ribs at least up to two vertebral centra in length (Padian 2008a, b; Dalla Vecchia 2014). The first eight cervicals of the juvenile Scaphognathus crassirostris specimens lack ribs, whereas cervicals 4-8 bear small cervical ribs in the adult (Bennett 2014); the cervical ribs are short also in Rhamphorbynchus muensteri (see Wellnhofer 1975a). All these non-monofenestratan pterosaurs have mid-cervical vertebrae that are stockier than those of monofenestratan pterosaurs.

The basal monofenestratan Darwinopterus modularis seems to lack cervical ribs and has cervical vertebrae that are much more elongated than those of the anurognathids (Lü et al. 2010a). "Cervical vertebrae more elongated than in other non-pterodactyloids" and "cervical ribs reduced" are synapomorphies of the Wukongopteridae according to Wang et al. (2010). Mid-cervical ribs are absent or reduced in the Pterodactyloidea and mid-cervical vertebrae are in general more elongated than in non-monofenestratan pterosaurs (Kellner 2003; Unwin 2003).

The morphology of the cervical segment of the vertebral column of the anurognathids, with reduced or absent cervical ribs and comparatively short and stocky cervical vertebrae, is more reminiscent of the condition in Scaphognathus crassirostris and Rhamphorbynchus muensteri than to that of other pterosaurs.

Sacrum. Bennett (2007) identified a comparatively high number (four or five) of sacral vertebrae in Anurognathus ammoni. He also noticed a configuration of the the ribs/transverse processes of the first and second sacral vertebrae in this taxon that is reminiscent of the holotype synsacrum of Mesadactylus ornithosphyos from the Upper Jurassic of the USA, suggesting that the latter is an anurognathid. The synsacrum of Mesadactylus ornithosphyos is composed of seven vertebrae. According to Wei et al. (2021: 12), the sacrum of Sinomacrops bondei also possesses ribs/transverse processes of the first sacral vertebra that are strongly inclined posteriorly, like those of Mesadactylus ornithosphyos; the long sacrum suggests the presence of many sacral vertebrae in the Chinese species. According to Hone (2020), the presence of a supraneural plate on the sacrum of Mesadactylus ornithosphyos suggests it may belong to a pterodactyloid (the original referral of Mesadactylus ornithosphyos by Jensen \& Padian 1989). However, the sacrum is poorly preserved in both specimens of Anurognathus ammoni (see Bennett 2007: figs. 2 and 9), Sinomacrops bondei (see Wei et al. (2021: fig. 5), and all other anurognathids. The sacrum of the rhamphorhynchid Dorygnathus banthensis (see Padian 2008a: fig. 19B) appears to be similar to that of Mesadactylus ornithosphyos (the ribs/transverse processes of the first sacral are inclined backward), although it is composed of only four vertebrae. The same shape and orientation of the ribs/transverse processes of the first sacral vertebra and the similar number of sacral vertebrae might imply a close relationship of Anurognathus ammoni and Dorygnathus banthensis; the shape and orientation of the ribs/transverse processes of the first sacral vertebra might support a relationship of Anurognathus ammoni and Dorygnathus banthensis with Mesadactylus ornithosphyos, or it may just be an homoplastic feature. This aspect needs further investigation.

Short tail - "Short tail" is a diagnostic feature of the Family Anurognathidae according to Bennett (2007: 395), while it is not considered as such by Hone (2020). The tails of the anurognathids are comparatively shorter than those of other non-pterodactyloid pterosaurs (Dalla Vecchia 2002; Lü et al. 2010a; Lü \& Hone 2012), but the relative tail size is somewhat variable within the clade. The longest anurognathid tail gets close in relative size to that of the basal monofenestratan Douzhanopterus zhengi (see Wang et al. 2017) and the shortest overlaps the pterodactyloid tail length range (Lü \& Hone 2012). Hone (2020) reports from eight to ?20 caudals in the anurognathids. The tail is short in Anurognathus ammoni (possibly 10 caudal vertebrae, Bennett 2007; tail $/$ humerus length ratio $=0.40$, tail $/$ femur length 
ratio $=0.50$; Jiang et al. 2015) and Vesperopterylus lamadongensis (no more than 15 caudal vertebrae; tail $/$ humerus length ratio $=0.44$, tail $/$ femur length ratio $=0.59$; Lü et al. 2018). Caudal vertebrae of these short-tailed taxa do not have elongated zygapophyses and filiform haemapophyseal processes. The tail of Luopterus mutoudengensis may be proportionally slightly longer (possibly 15 caudal vertebrae; tail $/$ humerus length ratio $=0.67 ;$ tail $/$ femur length ratio $=0.86$; Lü \& Hone 2012: fig. 3) and has filiform processes that Lü \& Hone (2012) interpreted as haemapophyseal processes only, while Wei et al. (2021) assume as probable that they represent both elongated zygapophyses and filiform haemapophyseal processes, but coded their presence as 'unknown' in the matrix of the phylogenetic analysis. The tail of Sinomacrops bondei is also relatively long (longer than the entire hind limb; Wei et al. 2021). The tail is partly preserved in specimen PIN 2585/4a of Batrachognathus volans and is comparatively long (the ratio of the preserved portion of the tail/humerus length $=1.47$; Costa et al. 2013) and has elongated zygapophyses and filiform haemapophyseal processes (Costa et al. 2013). The tail is comparatively long also in the unnamed specimen IVPP V16728 from the Middle-Upper Jurassic of China described by Jiang et al. (2015), which has at least 20 vertebrae, and its tail/humerus and tail/ femur length ratios equal 1.04 and 1.50, respectively. The caudal vertebrae of IVPP V16728 also show elongated zygapophyses and haemapophyseal processes. The unnamed specimen NJU-57003 from the Middle-Upper Jurassic of China reported by Yang et al. (2019: fig. 2a and f, SI fig. 1A) has a long tail, which is the proportionally longest anurognathid tail according to Hone (2020). The caudal segment of the vertebral column of NJU-57003 comprises 18 or19 vertebrae and is $41.8 \mathrm{~mm}$ long (the "total $418 \mathrm{~mm}$ " reported by Yang et al. 2019: SI 2 , is evidently a mistake); the tail/humerus length ratio is 1.45-1.52 (as humeri have different lengths) and the tail/femur ratio is 1.96 .

In the basal monofenestratan Douzhanopterus zhengi, tail/humerus length ratio is 1.73 , the tail is twice the length of femur, and there are 22 caudal vertebrae with elongated zygapophyses and haemapophyseal processes (Wang et al. 2017).

The structure of the tail is quite variable within the pterodactyloids (Bennett 2001; Codorniú 2005). The vertebral column of the tail of the so- called "Painten pro-pterodactyloid" (Tischlinger \& Frey 2013), recovered as a basal pterodactyloid in the phylogenetic analysis by Wu et al. (2017), has perhaps 17 vertebrae and bears elongated zygapophyses and haemapophyseal processes in its middle section; the tail/humerus and tail/femur length ratios are 0.71 and 0.75 , respectively. The tail/femur length ratio ranges $0.14-1.88$ in pterodactyloids according to Lü \& Hone (2012: tab. 2) with mean 0.68 $(\mathrm{N}=18)$, but only one (the relatively long-tailed Pterodaustro guinazui, with at least 22 caudal vertebrae) has a ratio $>1$ and the rest range $0.14-0.92$ (mean of 0.61). Excluding the basal "Painten pterodactyloid", pterodactyloid caudals lack very elongated zygapophyses and filiform haemapophyseal processes, although the zygapophyses of the mid-caudals of Pterodaustro are comparatively more elongated than in other pterodactyloids (Codorniú 2005).

According to Bennett (2007), Anurognathus ammoni and the pterodactyloids evolved short tails convergently because the caudal vertebrae are quite different in the two taxa, with those of Anurognathus ammoni being much wider transversely than anteroposteriorly long.

The results of the phylogenetic analyses here reported support the view that the Anurognathidae and the Pterodactyloidea convergently acquired comparatively short tails.

Narrow sternum. According to Hone (2020:1684), anurognathids have a narrow sternum "approximately the length of four dorsal vertebrae, and approximately the same width as the dorsal vertebral column", but this is not listed as a diagnostic feature of the clade in that paper. The sternum of other pterosaurs (both non-pterodactyloid and pterodactyloid) is a broad plate (Wellnhofer 1978: fig. 8; Lü et al. 2011: fig. 4; Dalla Vecchia 2014: fig. 4.2.2). Bennett (2007) did not consider the shape of the sternum a diagnostic feature of the Family Anurognathidae, although he retained "sternum broad" as a character shared by all pterosaurs except the anurognathids (p. 395). Andres et al. (2010) considered a narrow sternum an apomorphy of Anurognathus ammoni, because they accepted the identification by Bakhurina \& Unwin (1995) of a broad sternum in Batrachognathus volans (contra Bennett 2007, who apparently accepted Ryabinin's identification). Confusingly, the sternum of Batrachognathus volans has never been figured in any form, making verification of either shape difficult. The sternum is 
apparently absent (not preserved or missing) in the articulated skeletons of Dendrorbynchoides curvidentatus (see Unwin et al. 2000), Jeholopterus ningchengensis (see Wang et al. 2002; Lü et al. 2006; Kellner et al. 2009; Yang et al. 2019), Luopterus mutoudengensis (see Lü \& Hone 2012), Vesperopterylus lamadongensis (see Lü et al. 2018), and Sinomacrops bondei (see Wei et al. 2021). Thus, this feature needs further investigation.

Proximal end of the humeral head in dorsal view nearly symmetrical. "Humerus with small, extremely proximally placed deltopectoral crest" is a diagnostic feature of the Family Anurognathidae according to Bennett (2007: 395). According to Hone (2020: 1684), "proximal end of the humeral head in dorsal view nearly symmetrical i.e. the deltopectoral crest and medial crest are similar in size" is a diagnostic feature of the Anurognathidae. "Extremely proximally placed deltopectoral crest" is a somewhat ambiguous definition, as the deltopectoral crest is located at the proximal extremity of the humerus in all earliest pterosaurs (e.g., Dalla Vecchia 2009a: fig. 4). Furthermore, the shape of the deltopectoral crest appears to be somewhat variable within the anurognathid species (see Wei et al. 2021: fig. 10). Size and shape of the deltopectoral and "medial" crests appear relatively similar only in Dendrorbynchoides curvidentatus, while they are different in the other taxa. There are no remarkable differences between the humeri of the anurognathids and those of other early pterosaurs.

Long antebrachium. This has been considered a diagnostic feature of the Anurognathidae by Bennett (2007: 395), but not by Hone (2020). This elongation has not been quantified by Bennett (2007), thus the feature remains somewhat vague. The ulna is shorter than wing phalanx 1 in Anurognathus ammoni, Jeholopterus ningchengensis, Dendrorbynchoides curvidentatus, Luopterus mutoudengensis, Vesperopterylus lamadongensis and Sinomacrops bondei. Among non-pterodactyloid pterosaurs, the ulna is the longest element of the forelimb in Preondactylus buffarinii, Peteinosaurus zambellii, Dorygnathus banthensis, Sordes pilosus, Scaphognathus crassirostris, Jinchangopterus zhaoianus, Changchengopterus pani, Pterorbynchus wellnhoferi, Wukongopterus lii, Darwinopterus modularis, D. robustodens and D. linglongtaensis, and Kupengopterus sinensis (see Dalla Vecchia 2014).

Short and simple pteroid. "Pteroid simple rod no more than one-sixth of ulna length" has been considered a diagnostic feature of the Family Anu- rognathidae by Bennett (2007: 395). "Pteroid less than $1 / 5$ th of the length of the ulna" is diagnostic of the Anurognathidae according to (Hone 2020: 1684). The pteroids appear to be comparatively small and simple rods in both specimens of Anurognathus ammoni (see Bennett 2007), and in Dendrorbynchoides curvidentatus (see Unwin et al. 2000), Jeholopterus ningchengensis (see Wang et al. 2002; Lü et al. 2006), and Vesperopterylus lamadongensis (see Lü et al. 2018). However, the shape and size of the pteroid may be ontogenetically variable. The immature specimen of Carniadactylus rosenfeldi MPUM 6009 (see Dalla Vecchia 2018) has a comparatively small pteroid (Wild 1979: pl. 5, fig. 18); although both pteroids of MPUM 6009 are distally incomplete, the preserved part of the left one is only $16 \%$ the length of ulna. The pteroid of specimen MCSNB 3359 of Peteinosaurus zambellii (which shows many features of osteological immaturity) is less than $1 / 5$ the length of ulna (Dalla Vecchia 2014). The relative size of the pteroid seems to increase with absolute size of the individuals in Rhamphorbynchus muensteri, i.e., small individuals have comparatively shorter pteroids (see Wellnhofer 1975a: fig. 12a-b). The small size and simple shape of the anurognathid pteroids may be related to the early ontogenetic stage of the specimens, or it may represent a paedomorphic feature in mature individuals (Vidović \& Martill 2018). Notice that the pteroid/ulna length ratio may be somewhat misleading in representing the relative size of the pteroid in the different taxa, because the ulna is the second longest forelimb element in the anurognathids (a long antebrachium was considered a diagnostic feature of the anurognathids by Bennett 2007, as seen above), while it is comparatively shorter in other taxa (e.g. in Carniadactylus rosenfeldi).

Very short wing metacarpal. A very short and robust wing metacarpal is reported by Hone (2020) as a diagnostic feature of the anurognathids based on Witton (2013) and Vidović \& Martill (2018). However, this 'shortness' and 'robustness' should be quantified, as the wing metacarpals of non-pterodactyloid pterosaurs are considered synapomorpically 'short' compared with those of pterodactyloids and 'robust' compared to metacarpals I-III. Hone (2021: 1684) supported the shortness, affirming that the wing metacarpal is "less than $1 / 3$ rd humeral length" (i.e. humerus/wing metacarpal length ratio $>3.33$ ) in the anurognathids. In order of decreasing humeral length, the humerus/ 
wing metacarpal length ratio is actually ca. 2.75 (humerus $=71 \mathrm{~mm}$ ) in Vesperopterylus lamadongensis (see Lü et al. 2018), ca. 3.26 (humerus $=62 \mathrm{~mm}$ ) in the holotype of Jeholopterus ningchengensis (see Wang et al. 2002), 2.91 (humerus $=32 \mathrm{~mm}$ ) in Anurognathus ammoni (see Wellnhofer 1978), 2.99 (humerus = 27.8 $\mathrm{mm}$ ) in Dendrorbynchoides curvidentatus (see Unwin et al. 2000), 2.45 (humerus $=27 \mathrm{~mm}$ ) in Luopterus mutoudengensis (see Lü \& Hone 2012), and ca. 3.52 (humerus $=23.6 \mathrm{~mm}$ ) in Sinomacrops bondei (see Wei et al. 2021). Therefore, the ratio is quite variable, ranging 2.45-3.52. Apparently, this variability is not related to body size, as the second largest and the smallest individuals have the comparatively shortest metacarpals IV (ratio >3) in the sample. The same ratio ranges 1.62-2.89 in Triassic pterosaurs and is highest in juvenile individuals MCSNB 8950 (2.89) and MPUM 6009 (2.50) (Dalla Vecchia 2014). The humerus/wing metacarpal length ratio is 2.32-2.17 in Dimorphodon macronyx (see Sangster 2003), 2.39 in Campylognathoides ritteli (see Padian 2008b), 1.80 in Fenghuangopterus lii (see Lü et al. 2010b), 1.98-2.16 in Scaphognathus crassirostris (see Bennett 2014), 1.74 in Nesodactylus hesperius (see Colbert 1969), 1.96 in Qinglongopterus guoi (see Lü et al. 2012), 2.61 in Sordes pilosus (Unwin et al. 2000), 2.63 in Orientognathus chaoyangensis (see Lü et al. 2015), 1.66-1.86 in Changchengopterus pani (see Lü 2009; Zhou \& Schoch 2011), 1.82 in Pterorbynchus wellnhoferi (see Czerkas \& Ji 2002), 1.69 in Wukongopterus lii (see Wang et al. 2009), ca. 1.57 in Kunpengopterus sinensis (see Wang et al. 2010), 1.64-169 in Darwinopterus modularis (see Lü et al. 2010a), 1.67 in D. robustodens (see Lü et al. 2011), and 1.69-1.79 in D. linglongtaensis (in a single specimen; Wang et al. 2010). In a sample of seven individuals of Campylognathoides liasicus, the humerus/wing metacarpal length ratio ranges 1.96-2.41, with a mean of 2.21 (Padian 2008b). In a sample of 20 individuals of Dorygnathus banthensis, the humerus/wing metacarpal length ratio ranges 1.76-2.27 with a mean of 1.99 (Padian 2008a).

The largest available pterosaur sample to the species level is that of Rhamphorbynchus muensteri (see Wellnhofer 1975b). Rhamphorbynchus specimens have been divided into small, medium and large size-classes, corresponding to juvenile, subadult/ young adult and adult individuals of this species by Bennett (1995). The humerus/wing metacarpal length ratio ranges 1.27-2.92 in a sample of 26 individuals of the small size-class (Wellnhofer 1975b; see also Dalla Vecchia 2018: SI) and the mean is 1.69 , but only one individual has a ratio $>2$; eliminating this deviant ratio, the mean becomes 1.64. The same ratio ranges $1.55-2.15$ in a sample of 40 individuals of the medium size-class (Wellnhofer $1975 \mathrm{~b}$ ) and the mean is 1.84 , with $22.5 \%$ of values $\geq 2$. The large size class is represented by only two individuals and shows no difference with the medium size-class. Therefore, there is an evident increase of the ratio from the small size-class to the medium size-class, despite the negative allometric growth of the humerus with respect to body length and wing finger length (Bennett 1995: tab. 2).

Thus, some anurognathids have the shortest wing metacarpals with respect to the humerus (ratio $>3$ ) among pterosaurs, but not all of them have such extreme proportions, overlapping the ratio ranges of other pterosaurs. This feature is worth further investigation; it is evident that a much larger anurognathid sample is necessary to evaluate its actual importance.

The wing metacarpal is shorter than the other metacarpals in the two Anurognatbus ammoni specimens (Wellnhofer 1975b; Bennett 2007), which is unlike the condition in all other pterosaurs, including the other anurognathids; thus it appears to be an apomorphy of Anurognathus ammoni.

Flexibility of joints in wing finger. Bennett (2007) noticed that the specimens of Anurognathus ammoni, Dendrorbynchoides curvidentatus, and Jeholopterus ningchengensis (a sample of only four specimens when the author wrote the paper) have markedly flexed interphalangeal joints. He considered this a distinction from other pterosaurs, although he did not list it as a diagnostic feature of the Family Anurognathidae. Andres et al. (2010) considered this flexion to be a result of the disarticulation of the skeletons. Hone (2020: 1701) argued that this flexion "occurs in all specimens, even when the rest of the material is well articulated, and disarticulation of the wing phalanges is rare in all other pterosaurs". I am skeptical about the validity of this feature as an anurognathid synapomorphy until wing phalanges joints of anurognathids and other non-monofenestratan pterosaurs are studied as tridimensional structures and compared to look for differences. As argued by Andres et al. (2010), I also suspect that flexion may be taphonomically biased, but due mainly to the dorsoventral flattening of the anurognathid body rather than its disarticulation. 
Wing phalanx 4 bighly reduced or lost. The terminal wing phalanx is the shortest in all non-pterodactyloid pterosaurs (Dalla Vecchia 2014), but it is never reduced as in Jeholopterus ningchengensis (see Wang et al. 2002: fig. 1; Kellner et al. 2009: fig. 1), Luopterus mutoudengensis (see Lü \& Hone 2012: fig. 3), and Vesperopterylus lamadongensis (see Lü et al. 2018: fig. 2). In Anurognathus, there are no wing phalanges 4 and wing phalanx 3 is thin and tapering to a blunt point (Bennett 2007: fig. 2). Hone (2020) argued that Anurognathus ammoni had four wing phalanges per wing digit and that wing phalanx 4 is just unpreserved or covered by rock in Anurognathus specimens, but he did not give any evidence to support this view. Also the only figured specimen of Dendrorbynchoides curvidentatus seems to lack wing phalanges 4 (Unwin et al. 2000: fig. 2). Wing phalanx 4 is present in most pterodactyloids, but is generally very reduced in the azhdarchoids (Witton 2013) and was lost in Nyctosaurus and Beipiaopterus (see Bennett 2007). The loss of the wing phalanx 4 or its extreme reduction is a feature convergently acquired in anurognathids and pterodactyloids.

\section{Conclusions}

Anurognathids are a clade of pterosaurs characterized mainly by a peculiar skull and lower jaw. The morphology of the skull bones in relatively well-preserved specimens of the anurognathid $B a$ trachognathus volans shows that this pterosaur had an enormous skull fenestra originating from the confluence of the orbit and the antorbital fenestra and separated from the external naris by the ascending process of the maxilla. Posterior to this ascending process, the maxilla and jugal form a low bar bordering ventrally the orbitoantorbital fenestra. The broad fenestra hosted a very large eye. This large skull opening occurs also in Jeholopterus ningchengensis and is plausibly a synapomorphy of the anurognathids, with the possible exclusion of 'Dimorphodon' weintraubi. The revision of the data matrices of the phylogenetic analyses by Dalla Vecchia (2019) and Wei et al. (2021) according to this new reconstruction of the anurognathid skull shows that the anurognathids fall outside the Monofenestrata and are an advanced clade within the non-monofenestratan pterosaurs that appeared in the Early Jurassic. In both phylogenetic analyses, the Anurognathidae sensu Hone (2020) include the Early Jurassic ' $D i$ morphodon' weintraubi which, unfortunately, does not preserve much of the skull.

With only 15 specimens reported in the literature, most of which are poorly preserved or incomplete and often just preliminarily described, we are far from satisfactorily knowing anurognathid anatomy and its variability. Knowledge on these peculiar pterosaurs will benefit from the publication of detailed descriptions of the specimens belonging to Batrachognathus volans, Jeholopterus ningchengensis, Dendrorbynchoides curvidentatus, and 'Dimorphodon' weintraubi.

Acknowledgements: I thank Fabiana Costa Rodrigues Nunes for sharing photographs of the Batrachognathus volans specimens in 2012 and Andrea Cau for running the phylogenetic analysis of the matrix within TNT 1.5. I am grateful to the reviewers Adam Fitch and Borja Holgado Palacios for their valuable comments and suggestions. Once again, I am indebted with Cristina Lombardo for her editorial work.

\section{REFERENCES}

Andres B. (2010) - Systematics of the Pterosauria. PhD thesis, Yale University, New Haven, U.S.A.

Andres B., Clark J.M. \& Xu X. (2010) - A new rhamphorhynchid pterosaur from the Upper Jurassic of Xinjiang, China, and the phylogenetic relationships of basal pterosaurs. Journal of Vertebrate Paleontology, 30(1): 163-187.

Andres B. (2012) - The early evolutionary history and adaptive radiation of the Pterosauria. Acta Geologica Sinica, 86(6): 1356-1365.

Andres B. \& Myers T.S. (2013) - Lone star pterosaurs. Earth and Environmental Sciences Transactions of the Royal Society of Edimburgh, 103(3-4): 383-398.

Andres B., Clark J. \& Xu X. (2014) - The Earliest Pterodactyloid and the Origin of the Group. Current Biology, 24(9): 1011-1016.

Bakhurina N.N. (1988) - On the first rhamphorhynchoid from Asia: Batrachognathus volans Ryabinin 1948, from Upper Jurassic beds of Karatau. Byuleten' Moscowskogo Obschchestva Ispytatelei Prirody, Otdel Geologischeskii, 59(3): 130. [in Russian]

Bakhurina N.N. \& Unwin D.M. (1995) - A survey of pterosaurs from the Jurassic and Cretaceous of the former Soviet Union and Mongolia. Historical Biology, 10: $197-$ 245.

Bennett S.C. (1995) - A statistical study of Rhamphorbynchus from the Solnhofen Limestone of Germany: year-classes of a single large species. Journal of Paleontology, 69: 569580 .

Bennett S.C. (2001) - The osteology and functional morphology of the Late Cretaceous pterosaur Pteranodon. Part I. General description and osteology. Palaeontographica, A 260: 1-112. 
Bennett S.C. (2007) - A second specimen of the pterosaur Anurognathus ammoni. Paläontologische Zeitschrift, 81(4): 376398.

Bennett S.C. (2014) - A new specimen of the pterosaur Scaphognathus crassirostris, with comments on constraint of cervical vertebrae number in pterosaurs. Neues Jahrbuch für Geologie und Paläontologie, Abhandlungen, 271(3): 327-348.

Britt B.B., Dalla Vecchia F.M., Chure D.J., Engelmann G.F., Whiting M.F. \& Scheetz R.D. (2018) - Caelestiventus hanseni gen. et sp. nov. extends the desert-dwelling pterosaur record back 65 million years. Nature Ecology and Evolution, 2(9): 1386-1392.

Cheng X., Wang X., Jiang S. \& Kellner A.W.A. (2012) - A new scaphognathid pterosaur from western Liaoning, China. Historical Biology, 24(1): 101-111.

Clark J.M., Montellano M., Hopson J.A., Hernandez R. \& Fastowsky D.E. (1994) - An Early or Middle Jurassic tetrapod assemblage from the La Boca Formation, Northeastern Mexico. In: Fraser N.C. \& Sues H.-D. (eds.) - In the shadows of the dinosaurs - early Mesozoic tetrapods. Cambridge: Cambridge University Press, pp. 295-302.

Clark J.M., Hopson J.A., Hernandez R., Fastowsky D.E. \& Montellano M. (1998) - Foot posture in a primitive pterosaur. Nature, 391: 886-889.

Codorniú L.S. (2005) - Morfología caudal de Pterodaustro guinazui (Pterosauria: Ctenochasmatidae) del Cretácico de Argentina. Ameghiniana, 42(2): 505-509.

Colbert E.H. (1969) - A Jurassic pterosaur from Cuba. American Museum Novitates, 2370: 1-26.

Costa F., Alifanov V., Dalla Vecchia F.M. \& Kellner A.W.A. (2013) - On the presence of an elongated tail in an undescribed specimen of Batrachognathus volans (Pterosauria: Anurognathidae: Batrachognathinae). In: Sayão J.M., Costa F., Bantim R.A.M., Kellner A.W.A. (Eds) - Short communications, Rio Ptero 2013 - International Symposium on Pterosaurs. Rio de Janeiro: 54-56. Universidade Federal do Rio de Janeiro, Museu Nacional, Rio de Janeiro.

Czerkas S.A. \& Ji Q. (2002) - A new rhamphorhynchoid with a headcrest and complex integumentary structures. The Dinosaur Museum Journal, 1: 16-41.

Dalla Vecchia F.M. (2002) - A caudal segment of a Late Triassic pterosaur (Diapsida, Pterosauria) from Northeastern Italy. Gortania, 23 (2001): 31-58.

Dalla Vecchia F.M. (2009a) - Anatomy and systematics of the pterosaur Carniadactylus gen. n. rosenfeldi (Dalla Vecchia, 1995). Rivista Italiana di Paleontologia e Stratigrafia, 115: 159-188.

Dalla Vecchia F.M. (2009b) - Austriadactylus (Diapsida, Pterosauria) from the Norian (Upper Triassic) of northeastern Italy. Rivista Italiana di Paleontologia e Stratigrafia, 115: 291-304.

Dalla Vecchia F.M. (2013) - Triassic pterosaurs. In: Nesbitt S.J., Desojo J.B., Irmis R.B. (Eds) -Anatomy, Phylogeny and Palaeobiology of Early Archosaurs and their Kin. Geological Society London, Special Publications, 379: 119-155.

Dalla Vecchia F.M. (2014) - Gli pterosauri triassici. Pubblicazione del Museo Friulano di Storia Naturale n. 54, Museo
Friulano di Storia Naturale, Udine, 319 pp.

Dalla Vecchia F.M. (2018) - Comments on Triassic pterosaurs with a commentary on the "ontogenetic stages" of Kellner (2015) and the validity of Bergamodactylus wildi. Rivista Italiana di Paleontologia e Stratigrafia, 124(2): 317-341.

Dalla Vecchia F. M. (2019) - Seazzadactylus venieri gen. et sp. nov., a new pterosaur (Diapsida: Pterosauria) from the Upper Triassic (Norian) of northeastern Italy. PeerJ, 7 : e7363.

Dalla Vecchia F.M., Riera V., Oms O., Dinàres-Turell J., Gaete R., Galobart À. (2013) - The last pterosaurs: First record from the uppermost Maastrichtian of the Tremp Syncline (Northern Spain). Acta Geologica Sinica, 87(5): 1198-1227.

Döderlein L. (1923) - Anurognathus ammoni, ein neuer Flugsaurier. Sitzungsberichte der Bayerischen Akademie der Wissenschaften, Mathematisch-Naturwissenschaftlichen, 1923: 117 164.

Ezcurra M.D., Nesbitt S.J., Bronzati M., Dalla Vecchia F.M., Agnolin F.L., Benson R.B.J., Brissón Egli F., Cabreira S.F., Evers S.W., Gentil A.R., Irmis R.B., Martinelli A.G., Novas F.E., da Silva L.R., Smith N.D., Stocker M.R., Turner A. H. \& Langer M. C. (2020) - Enigmatic dinosaur precursors bridge the gap to the origin of Pterosauria. Nature, 588 (7838): 445-449.

Gao K.Q., Li Q., Wei M., Pak H.\& Pak I. (2009) - Early Cretaceous birds and pterosaurs from the Sinuiju Series, and geographic extension of the Jehol Biota into the Korean Peninsula. Journal of the Paleontological Society of Korea, 25(1): 57-61.

Goloboff P. \& Catalano S. (2016) - TNT version 1.5, including a full implementation of phylogenetic morphometrics. Cladistics, 32(3): 221-238.

Hone D.W.E. (2020) - A review of the taxonomy and palaeoecology of the Anurognathidae (Reptilia, Pterosauria). Acta Geologica Sinica, 94(5): 1676-1692.

Jensen J.A. \& Padian K. (1989) - Small Pterosaurs and Dinosaurs from the Uncompahgre Fauna (Brushy Basin Member, Morrison Formation: ?Tithonian), Late Jurassic, Western Colorado. Journal of Paleontology, 63: 364-373.

Ji S. \& Ji Q. (1998) - A new fossil pterosaur (Rhamphorhynchoidea) from Liaoning. Jiangsu Geology, 22(4):199-206. [in Chinese]

Ji Q. \& Yuan C.X. (2002) - Discovery of two kinds of protofeathered pterosaurs in the Mesozoic Daohugou Biota in the Ningcheng region and its stratigraphic and biologic significances. Geological Review, 48(2): 221-224.

Jiang S., Wang, Cheng X., Rodrigues Costa F., Huang J., Kellner A.W.A. (2015) - Short note on an anurognathid pterosaur with a long tail from the Upper Jurassic of China. Historical Biology, 27(6): 718-722.

Kellner A.W.A. (2003) - Pterosaur phylogeny and comments on the evolutionary history of the group. Geological Society, London, Special Publications, 217: 105-137.

Kellner A.W.A., Wang X., Tischlinger H., Campos D.A., Hone D.W.E. \& Meng X. (2009) - The soft tissue of Jeholopterus (Pterosauria, Anurognathidae, Batrachognathidae) and the structure of the pterosaur wing membrane. Proceed- 
ings of the Royal Society, Series B, 277: 321-329.

Kuhn O. (1967) - Die fossile Wirbeltierklasse Pterosauria. Oeben, Krailling bei München, 52 pp.

Lü J. (2009) - A new non-pterodactyloid pterosaur from Qinglong County, Hebei Province of China. Acta Geologica Sinica, 83: 189-199.

Lü J. \& Hone D.W. (2012) - A new Chinese anurognathid pterosaur and the evolution of Pterosaurian tail lengths. Acta Geologica Sinica, English Edition, 86(6): 1317-1325.

Lü J. \& Ji Q. (2006) - Preliminary results of a phylogenetic analysis of the pterosaurs from Western Liaoning and surrounding areas. Journal of the Paleontological Society of Korea, 22: 239-261.

Lü J., Ji S., Yuan C. \& Ji Q. (2006) - Pterosaurs from China. Geological Publishing House, Beijing, 147 pp.

Lü J., Xu L., Chang H. \& Zhang X. (2011) - A new darwinopterid pterosaur from the Middle Jurassic of Western Liaoning, Northeastern China and its ecological implications. Acta Geologica Sinica, 85: 507-514.

Lü J., Unwin D.M., Jin X., Liu Y. \& Ji Q. (2010a) - Evidence for modular evolution in a long-tailed pterosaur with a pterodactyloid skull. Proceedings of the Royal Society B, 7: 383-389.

Lü J., Fucha X. \& Cheng J. (2010b) - A new scaphognathine pterosaur from the Middle Jurassic of western Liaoning, China. Acta Geoscientica Sinica, 31(2): 263-266.

Lü J., Unwin D.M., Bo Z., Chunling G. \& Caizhi S. (2012) - A new rhamphorhynchid (Pterosauria: Rhamphorhynchidae) from the Middle/Upper Jurassic of Qinglong, Hebei Province, China. Zootaxa, 3158: 1-19.

Lü J., Meng Q., Wang B., Liu D., Shen C. \& Zhang Y. (2018) - Short note on a new anurognathid pterosaur with evidence of perching behaviour from Jianchang of Liaoning Province, China. Geological Society, London, Special Publications, 455: 95-104.

Lü J., Pu H., Xu L., Wei X., Chang H. \& Kundràt M. (2015) A new rhamphorhynchid pterosaur (Pterosauria) from Jurassic deposits of Liaoning Province, China. Zootaxa, 3911 (1): 119-129.

Nesbitt S.J. (2011) - The early evolution of archosaurs: relationships and the origin of major clades. Bulletin of the American Museum of Natural History, 352: 1-292.

Nopcsa F. (1928) - The genera of reptiles. Palaeobiologica, 1: 163-188.

Ősi A., Prondvai E., Frey E. \& Pohl B. (2010) - New Interpretation of the Palate of Pterosaurs. The Anatomical Record, 293: 243-258.

Padian K. (2008a) - The Early Jurassic pterosaur Dorygnathus banthensis (Theodori, 1830). Special Papers in Palaeontology, 80: 1-64.

Padian K. (2008b) - The Early Jurassic pterosaur Campylognathoides Strand, 1928. Special Papers in Palaeontology, 80: 65107.

Romer A.S. (1956) - Osteology of Reptiles. 3rd edition (1976). University Press, Chicago \& London, xxi +772 pp.

Ryabinin A.N. (1948) - Remarks on a flying reptile from the Jurassic of Karatau. Trudy Paleontologischeskogo Instituta Akademii nauk SSSR, 15(1): 86-93. [in Russian]
Sangster S. (2003) - The anatomy, functional morphology and systematics of Dimorphodon macronyx (Diapsida: Pterosauria). $\mathrm{PhD}$ thesis, University of Cambridge, Cambridge $(\mathrm{UK})$.

Sharov A.G. (1971) - New flying reptiles from the Mesozoic of Kazakhstan and Kirghizia. Trudy Paleontologischeskogo Instituta Akademii nauk SSSR, 130: 104-113. [In Russian]

Swofford D.L. (2002) - PAUP 4.0b 10. Sinauer Associates, Sunderland, Massachusetts.

Tischlinger H. \& Frey E. (2013) - Ein neuer Pterosaurier mit Mosaikmerkmalen basaler und pterodactyloider Pterosauria aus dem Ober-Kimmeridgium von Painten (Oberpfalz, Deutschland). Archaeopteryx 31: 1-13.

Unwin D.M. (2003) - On the phylogeny and evolutionary history of pterosaurs. Geological Society, London, Special Publications, 217: 139-190.

Unwin D.M. (2006) - The pterosaurs from deep time. Pi Press, New York, 347 pp.

Unwin D.M. \& Bakhurina N.N. (2000) - Pterosaurs from Russia, Middle Asia and Mongolia. In: Benton M.J., Shishkin M.A., Unwin D.M. \& Kurochkin E.N. (eds.), The age of dinosaurs in Russia and Mongolia. Cambridge: Cambridge University; pp. 420-433.

Unwin D. M., Lü J., Bakhurina N.N. (2000) - On the systematic and stratigraphic significance of pterosaurs from the Lower Cretaceous Yixian Formation (Jehol Group) of Liaoning, China. Mitteilungen aus dem Museum für Naturkunde Berlin, Geowissenschaftliche Reihe, 3(1): 181-206.

Vidović S.U. \& Martill D.M. (2018). The taxonomy and phylogeny of Diopecephalus kochi (Wagner,1837) and 'Germanodactylus rhamphastinus' (Wagner, 1851). Geological Society, London, Special Publications, 455(1):125-147.

Wang X., Zhou Z., Zhang F. \& Xu X. (2002) - A nearly completely articulated rhamphorhynchoid pterosaur with exceptionally well preserved wing membranes and 'hairs' from Inner Mongolia, northeast China. Chinese Science Bulletin, 47(3): 226-230.

Wang X., Kellner A.W.A., Jiang S.X. \& Meng X. (2009) - An unusual long tailed pterosaur with elongated neck from western Liaoning of China. Anais da Academia Brasileira de Ciências, 81(4): 793-812.

Wang X., Kellner A.W.A., Jiang S., Cheng X., Meng X. \& Rodrigues T. (2010) - New long-tailed pterosaurs (Wukongopteridae) from western Liaoning, China. Anais da Academia Brasileira de Ciências, 82(4): 1045-1062.

Wang X., Rodrigues T., Jiang S.X., Cheng X. \& Kellner A.W.A. (2014) - An Early Cretaceous pterosaur with an unusual mandibular crest from China and a potential novel feeding strategy. Scientific Reports, 4: 6329.

Wang X., Jiang S.X., Zhang J., Cheng X., Yu X., Li Y., Wei J. \& Wang X. (2017) - New evidence from China for the nature of the pterosaur evolutionary transition. Scientific Reports, 7: 42763, 9 pp.

Wei X., Pêgas R.V., Shen C., Guo Y., Ma W., Sun D. \& Zhou X. (2021) - Sinomacrops bondei, a new anurognathid pterosaur from the Jurassic of China and comments on the group. Peer], 9: e11161.

Wellnhofer P. (1970) - Die Pterodactyloidea (Pterosauria) 
der Oberjura-Plattenkalke Süddeutschlands. Bayerische Akademie der Wissenschaften Mathematisch-Wissenschaftlichen Klasse, Abhandlungen, 141: 1-33.

Wellnhofer P. (1975a) - Die Rhamphorhynchoidea (Pterosauria) der Oberjura-Plattenkalke Süddeutschlands. Teil I: Allgemaine Skelettmorphologie. Palaeontographica, A 148: 1-33.

Wellnhofer P. (1975b) - Die Rhamphorhynchoidea (Pterosauria) der Oberjura-Plattenkalke Süddeutschlands. Teil II: Systematische Beschereibung. Palaeontographica, A 148: 132-186.

Wellnhofer P. (1978) - Pterosauria. In: Wellnhofer P. (Ed.) Handbuch der Paläoherpetologie, Part 19. Gustav Fisher, Stuttgart, $82 \mathrm{pp}$.

Wellnhofer P. (1991) - The Illustrated Encyclopedia of Pterosauria. Salamander Book, London, 192 pp.

Wild R. (1979) - Die Flugsaurier (Reptilia, Pterosauria) aus der Oberen Trias von Cene bei Bergamo, Italien. Bollettino della Società Paleontologica Italiana, 17: 176-256.
Witton M.P. (2013) - Pterosaurs: natural history, evolution, anatomy. Princeton University Press, Princeton ad Oxford, $291 \mathrm{pp}$.

Wu W.H., Zhou C.F. \& Andres B. (2017) - The toothless pterosaur Jidapterus edentus (Pterodactyloidea: Azhdarchoidea) from the Early Cretaceous Jehol Biota and its paleoecological implications. PLOS ONE, 12(9): e0185486.

Yang Z., Jiang B., McNamara,M.E., Kearns S.L., Pittman M., Kaye T.G., Orr P.J., Xu X. \& Benton M.J. (2019) - Pterosaur integumentary structures with complex feather-like branching. Nature ecology \& evolution, 3: 24-30.

Zhou C.-F. (2014) - Cranial morphology of a Scaphognathus-like pterosaur, Jianchangnathus robustus, based on a new fossil from the Tiaojishan Formation of western Liaoning, China, Journal of Vertebrate Paleontology, 34(3): 597-605.

Zhou C.-F. \& Schoch R.R. (2011) - New material of the non-pterodactyloid pterosaur Changchengopterus pani Lü, 2009 from the Late Jurassic Tiaojishan Formation of western Liaoning. Neues Jahrbuch für Geologie und Paläontologie, Abhandlungen, 260: 265-275. 